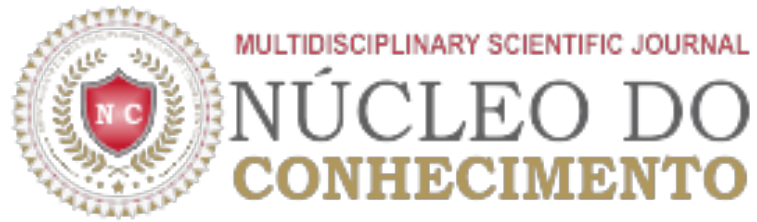

\section{A Educação Ambiental e o uso dos Recursos Hídricos dentro de uma Indústria de Cervejaria no Estado do Pará / PA - Brasil}

\author{
SOUZA, Endeson ${ }^{[1]}$ OLIVEIRA, Euzébio de ${ }^{[2]}$
}

SOUZA, Endeson; OLIVEIRA, Euzébio de. A educação ambiental e o uso de recursos hídricos dentro de uma indústria de cervejaria no estado do Pará / PA - Brasil. Revista Científica Multidisciplinar Núcleo do Conhecimento. Ano 01, Ed. 05, Vol. 02, pp. 59-82, Maio de 2016. ISSN: 2448-0959

\section{RESUMO}

O artigo apresenta uma reflexão sobre como se pode relacionar e caminhar de forma coesa, sem prejuízos para ambas as partes na questão em que envolve educação ambiental e uso dos recursos hídricos junto à modernização e desenvolvimento dentro de uma indústria, nesse caso uma indústria de cervejaria. Portanto, deve-se sim, pensar e agir em busca de uma harmonia entre as partes de desenvolvimento e o meio ambiente em que vivemos. A Busca pela preservação e principalmente saber usufruir de forma adequada e racional dos recursos naturais, para que estes, estejam disponíveis tanto no presente, quanto em tempos futuros.

Palavras Chaves: Educação Ambiental. Recursos Hídricos. Desenvolvimento Industrial. Gestão.

\section{INTRODUÇÃO}

Nos últimos anos, a proteção, conservação, aproveitamento racional e a garantia dos usos múltiplos dos recursos ambientais têm sido objeto central de preocupação de administradores públicos, pesquisadores, entidades da sociedade civil e movimentos sociais. Diversos organismos nacionais e internacionais têm discutido a problemática e desenvolvimento sustentável e progresso, foram formulados pressupostos baseados na conservação integrada e sustentabilidade ambiental para nortear as diversas práticas de gestão. Existe todo um aparato institucional - consubstanciado em legislações, que legitima essas ações. Enfim, há uma congruência de ações no sentido de garantir para as atuais e futuras gerações a disponibilidade dos recursos que se encontra em nossos tempos e que são essenciais para a existência da vida (MAXIMIANO, 2000).

Contudo, apesar de todos os avanços alcançados, ainda se verifica a necessidade de se desenvolverem 
ações mais concretas - que de fato garantam uma gestão eficiente, eficaz e efetiva dos recursos ambientais e do desenvolvimento industrial sem que haja grandes problemas nessa relação. Para tanto, a cada momento que se passa verifica-se a importância dos diversos órgãos da sociedade em que, busca não somente a conscientização, mas a atitude de se desenvolver ações para que haja a integridade entre desenvolvimento industrial e meio ambiente, sustentabilidade do sistema (MAXIMIANO, 2000).

Neste sentido, o presente artigo se propõe a discutir os aspectos centrais da articulação da gestão industrial, realizar estudos sobre a educação ambiental e o uso dos recursos hídricos e como é feito o processo de preparação da cerveja dentro da indústria de cervejaria CERPASA, visando obter informações de como se dá este processo dentro da produção industrial de bebidas, em uma nova visão de mercado voltado as questões socioambientais. Nesse caso uma indústria de cervejaria com a gestão da educação ambiental e uso dos recursos hídricos, com vistas a assegurar a sustentabilidade de que tanto se espera entre ambas as partes que se envolvem há anos, indústria, lucro, desenvolvimento sustentável, desenvolvimento social, político, econômico. Para tanto, num primeiro momento, o artigo enfoca a problemática sobre o tema pesquisado e seus respectivos conceitos; em seguida, faz uma discussão acerca das novas políticas de mercado consumidor ligado cada vez mais as questões ambientais; e, por último, tece algumas considerações finais.

\section{METODOLOGIA}

A metodologia utilizada neste artigo cientifico, se deu em um primeiro momento seguindo um estudo de analise bibliográfica sobre o processo histórico e conceitual de Educação Ambiental e Uso dos Recursos Hídricos voltando tal estudo para a indústria de cervejaria. Em um segundo momento foi realizado a pesquisa histórica da indústria de cervejaria CERPASA por meio de entrevista dialogada com o vicepresidente da empresa. Posteriormente realizou-se uma pesquisa de campo por meio de visita técnica dentro da indústria. Utilizou-se também de recursos fotográficos para registros de imagens.

\section{ÁREA DE ESTUDO}

A Cervejaria CERPASA (Fig. 01), foco da presente pesquisa, está localizada na Rodovia Arthur Bernardes, 7699, no município de Belém, Estado do Pará, Brasil. 


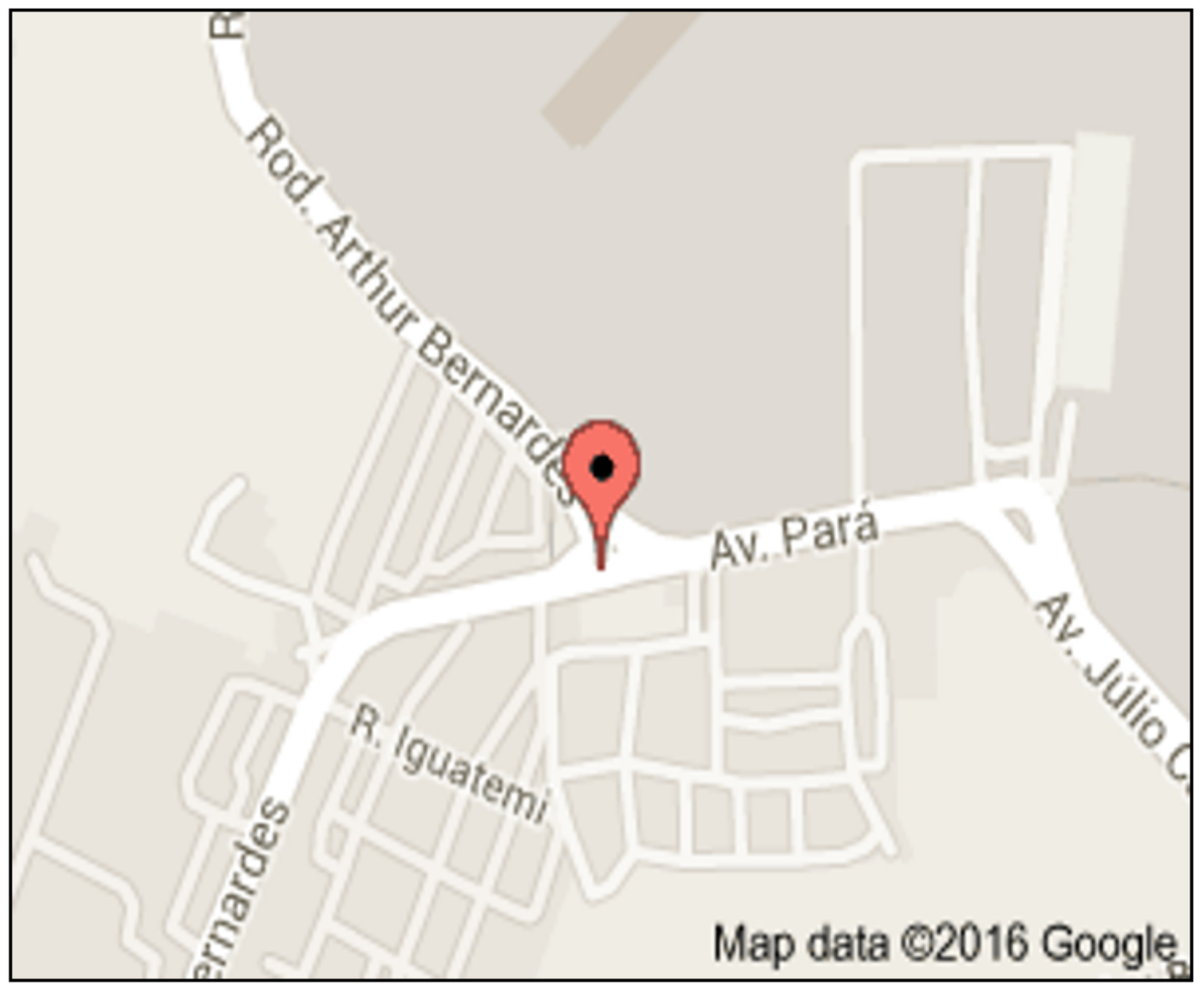

Figura 01: Localização da Indústria de Cervejaria CERPASA S/A Rod Arthur Bernardes, 7699 - Belém PA, 66816-000? - (0xx)91 3204-7272.

\section{RESULTADOS E DISCUSSÃO}

Meio Ambiente Educação Ambiental, Sustentabilidade e Desenvolvimento Sustentável, Recursos Hídricos, Indústria e Gestão.

A reflexão sobre as práticas sociais, em um contexto marcado pela degradação permanente do meio ambiente e do seu ecossistema, envolve uma necessária articulação com a produção de sentidos sobre a educação ambiental. A dimensão ambiental configura-se crescentemente como uma questão que envolve um conjunto de atores. Tomando-se como referência o fato de a maior parte da população brasileira viver em cidades, observa-se uma crescente degradação das condições de vida, refletindo uma crise ambiental. Isto nos remete a uma necessária reflexão sobre os desafios para mudar as formas de pensar e agir em torno da questão ambiental em uma perspectiva contemporânea (ODUM, 2001).

Para Leff (2001) a impossibilidade de resolver os crescentes e complexos problemas ambientais e reverter 
suas causas sem que ocorra uma mudança radical nos sistemas de conhecimento, dos valores e dos comportamentos gerados pela dinâmica de racionalidade existente, fundada no aspecto econômico do desenvolvimento. Mas na verdade precisamos nos impregnar de conceitos básicos da geografia, para aí sim iniciarmos e entendermos como podemos lidar com as questões ambientais, portanto, será que estamos preparados para discutir o que é meio ambiente, então meio ambiente pode ser abordado da seguinte maneira, "o meio ambiente é tudo que está a nossa volta! É a nossa vida... todos fazemos parte do meio ambiente"; O conjunto de condições, leis, influências e interações de ordem física, que permite, abriga e rege a vida em todas as suas formas; há também como em qualquer outro modo de pensar a evolução dos pensamentos científicos do conceito abordado como, além do fator natural e físico, o cultural, o artificial e o meio ambiente do trabalho. São conceitos de certa forma simples, mas que influenciam de forma direta na vida dos seres de um determinado ambiente (BRAGA, 1999).

Outro aspecto relevante dentro os conceitos básicos que deveríamos saber, da mesma forma que aprendemos a falar é o envolvimento das questões sobre educação ambiental. Nestes tempos em que a informação assume um papel cada vez mais relevante, ciberespaço, multimídia, internet, a educação para a cidadania representa a possibilidade de motivar e sensibilizar as pessoas para transformar as diversas formas de participação na defesa da qualidade de vida. Nesse sentido cabe destacar que a educação ambiental assume cada vez mais uma função transformadora, na qual a corresponsabilização dos indivíduos torna-se um objetivo essencial para promover um novo tipo de desenvolvimento - o desenvolvimento sustentável (ALFONSIN, 2001).

Entende-se, portanto, que a educação ambiental é condição necessária para modificar um quadro de crescente degradação socioambiental, mas ela ainda não é suficiente, pois se converte em "mais uma ferramenta de mediação necessária entre culturas, comportamentos diferenciados e interesses de grupos sociais para a construção das transformações desejadas" (BRAGA, 1999). Sendo que, temos também, que a educação ambiental "é a utilização de técnicas racionais de exploração de recursos naturais, juntamente com a agregação de tecnologia e, por extensão, de valor aos produtos extraídos da natureza, a recuperação e o aproveitamento de áreas degradadas, através de atividades que ampliam a renda da população, elementos capaz de atender a necessidade das gerações do presente e do futuro, com conservação do patrimônio natural" (ODUM, 2001); educação ambiental, "é um processo permanente no quais os indivíduos e a comunidade toma consciência do seu meio ambiente e adquirem conhecimento, valores, habilidade, experiências, determinação, tornando-se aptos a agir, individual, coletivamente, e resolver problemas ambientais presentes e futuros". (IBAMA, 1993). Portanto, educação ambiental deve estar presente em todas as atividades e aspectos da vida do cidadão responsável e preocupado com presente e com o futuro de todos os seres vivos. É entendida como importante instrumento para a construção, a expansão e a consolidação de espaços de participação da sociedade civil, necessária para um novo padrão de desenvolvimento no qual a regulação pública se dê com base nos princípios da emancipação e da responsabilidade socioambiental (BIBLIOTECA NACIONAL DIGITAL, 2010).

Um grande desafio é construir uma Nação que, sob a ética da sustentabilidade, seja ecologicamente correta, economicamente viável e socialmente justa, é uma tarefa e um desafio para todos nós cidadãos. Pensar em sustentabilidade e atuar em Educação Ambiental significa enfrentar esse desafio. Mas, a problemática da sustentabilidade assume neste novo século um papel central na reflexão sobre as dimensões do desenvolvimento e das alternativas que se configuram (BIBLIOTECA NACIONAL DIGITAL, 2010). 
O quadro socioambiental que caracteriza as sociedades contemporâneas revela que o impacto dos humanos sobre o meio ambiente tem tido consequências cada vez mais complexas, tanto em termos quantitativos quanto qualitativos, então sustentabilidade poderia ser: "um meio de configurar a civilização e atividades humanas, de tal forma que a sociedade, os seus membros e as suas economias possam preencher as suas necessidades e expressar o seu maior potencial no presente, e ao mesmo tempo preservar a biodiversidade e os ecossistemas naturais, planejando e agindo de forma a atingir próeficiência na manutenção indefinida desses ideais" (ODUM, 2001).

Mas não se engane, há uma diferença entre sustentabilidade e desenvolvimento sustentável, para isso entende-se que, o conceito de desenvolvimento sustentável surge para enfrentar a crise ecológica, sendo que pelo menos duas correntes alimentaram o processo. Uma primeira, centrada no trabalho do Clube de Roma, reúne suas ideias, publicadas sob o título de Limites do crescimento em 1972, segundo as quais, para alcançar a estabilidade econômica e ecológica propõe-se o congelamento do crescimento da população global e do capital industrial, mostrando a realidade dos recursos limitados e indicando um forte viés para o controle demográfico. Uma segunda está relacionada com a crítica ambientalista ao modo de vida contemporâneo, e se difundiu a partir da Conferência de Estocolmo em 1972. Tem como pressuposto a existência de sustentabilidade social, econômica e ecológica. Estas dimensões explicitam a necessidade de tornar compatível a melhoria nos níveis e qualidade de vida com a preservação ambiental. Surge para dar uma resposta à necessidade de harmonizar os processos ambientais com os socioeconômicos, maximizando a produção dos ecossistemas para favorecer as necessidades humanas presentes e futuras (BRASIL, 1993).

Em síntese sustentabilidade é: "a capacidade de criar processos, produtos, serviços, cultura, enfim, tudo que é construído ou criado pelo ser humano de forma a não causar um impacto negativo em seu entorno", enquanto que desenvolvimento sustentável é: "um conjunto de ações voltadas à solução ou, no mínimo, à redução de grandes problemas de ordem econômica, ambiental e social, tais como esgotamento de recursos naturais, desigualdade social ascendente e crescimento econômico ilimitado, são pilares a serem alcançados de forma coesa na relação homem natureza, para se obter um equilíbrio" (BRASIL, 1993).

Não se prenda em sustentabilidade e desenvolvimento sustentável, voltado apenas as questões ambientais, veja que até agora se relaciona com o ambiente em que vivemos, mas em sua grande parte envolve exclusivamente o principal agente transformador desse ambiente que é o ser humano, outros exemplos para solidificar tais pensamento e quebras desses paradigmas é a sequência apresentada (Fig. 02) sobre sustentabilidade onde percebe-se que há outras variantes do assunto sustentabilidade (BRASIL, 1997). 


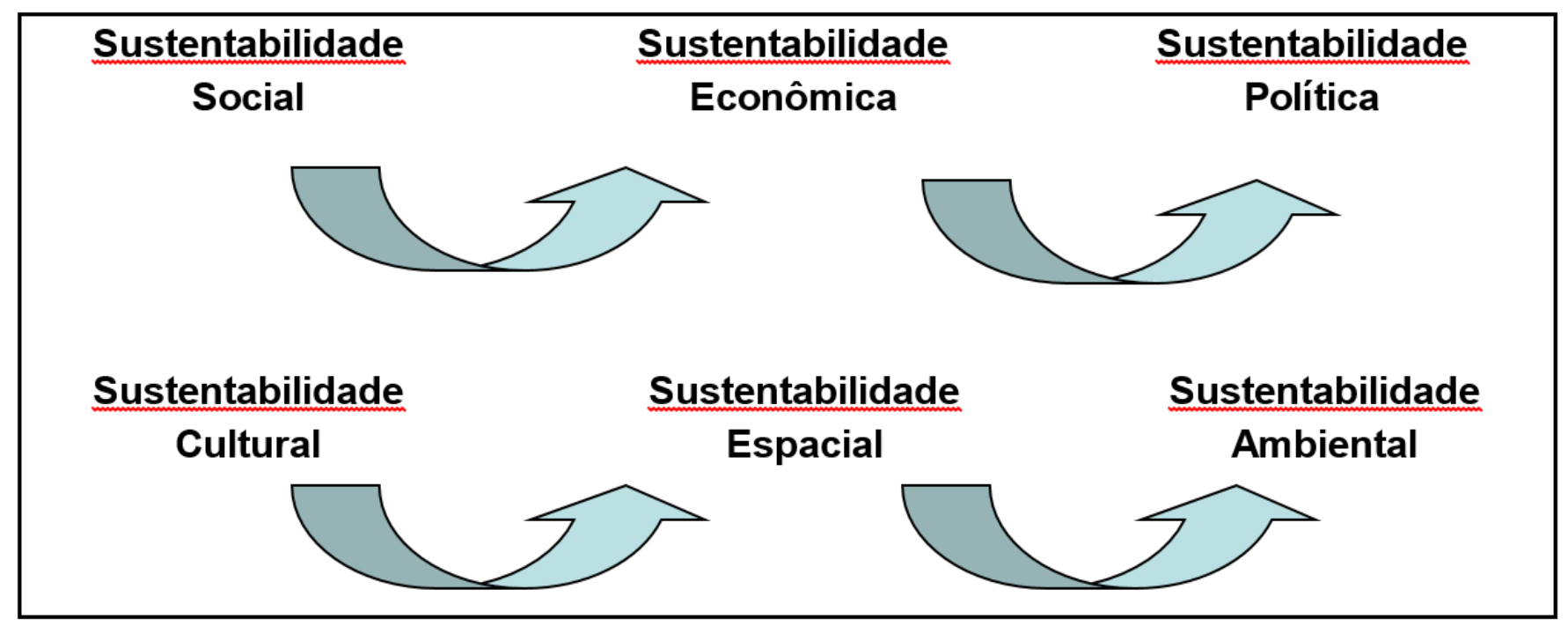

Figura 2: Variantes de sustentabilidade (BRASIL, 1997).

A água é um mineral presente em toda a Natureza, nos estados sólido, líquido e gasoso. É um recurso natural peculiar, pois se renova pelos processos físicos do ciclo hidrológico em que a Terra se comporta como um gigantesco destilador, pela ação do calor do Sol e das forças da gravidade. É, ainda, parte integrante dos seres vivos, e essencial à vida (BRASIL, 1997).

Um atributo notável da água é ser bem de múltiplos usos, destinando-se aos mais diversos fins, como abastecimento público, geração de energia elétrica, navegação, cuidado aos animais, suprimento industrial, crescimento de culturas agrícolas, conservação da flora e da fauna, recreação e lazer. Além disso, recebe, dilui e transporta esgotos domésticos, efluentes industriais e resíduos das atividades rurais e urbanas. $\mathrm{Na}$ maioria das vezes consegue assimilar esses despejos, regenerando-se pelo emprego de processos físicos, químicos e biológicos. No entanto, e com muita frequência, verifica-se a concentração de populações humanas, de indústrias, de atividades agrícolas e socioeconômicas fazendo uso excessivo da capacidade hídrica das bacias, de regiões hidrográficas e dos aquíferos subterrâneos. Sob essas condições, a água passa a ser escasso, o que leva à geração de conflitos entre seus diversos tipos de usos e usuários. Nas regiões semiáridas a escassez resulta das baixas disponibilidades hídricas e das irregularidades climáticas. Já nas regiões úmidas, e devido à sua contaminação, a água se torna indisponível para os usos mais exigentes quanto aos padrões de qualidade, dando origem também à escassez.

Portanto, recursos hídricos conceitualmente é a utilização da água em beneficio de todos que necessitam de tal bem, seja ele economicamente ou em outros aspectos da vida (BRASIL 1993).

Outro aspecto fundamental da água é o desequilíbrio provocado pelos eventos hidrológicos extremos, como as secas e as inundações. As secas trazem enormes problemas à imensa população brasileira das regiões semiáridas, causam pobreza, desnutrição e êxodo para as grandes cidades. As enchentes, agravadas pelo desmatamento e pela impermeabilização do solo urbano, são responsáveis por prejuízos econômicos e sociais incalculáveis e pelos riscos à saúde e à qualidade de vida dos habitantes das áreas assoladas (BRASIL, 1997). 
A poluição e a contaminação da água são as principais causas da incidência de enfermidades, em especial nas populações de baixa renda não atendidas pelos sistemas de abastecimento de água potável e de coleta e disposição de esgotos sanitários. As doenças de veiculação hídrica causam o maior número de internações hospitalares e nomeiam grande parte dos índices de mortalidade infantil (ALFONSIN, 2001).

A utilização econômica fez com que a água passasse a ser reconhecida como um recurso hídrico, semelhante aos recursos minerais quando utilizados economicamente. Por outro lado, ou seja, não somente como recurso econômico e sim também como utilização para qualquer tipo de uso. A escassez da água está fazendo com que se torne não mais um bem livre, abundante e disponível a todos, mas um recurso parco, ao qual é atribuído valor econômico e cuja utilização deve ser objeto de pagamento pelos usuários (ODUN, 2001).

Segundo avaliações efetuadas no âmbito do Decênio Hidrológico Internacional da UNESCO (2003), estima-se que a disponibilidade hídrica da Terra atinja a 1.380 milhões de $\mathrm{km}^{3}$ de água salgada, ou seja, $97,3 \%$ do total. A água doce corresponde aos restantes $2,7 \%$ e forma um volume de 38 milhões de $\mathrm{km}^{3}$, dos quais $77,2 \%$ encontram-se em estado sólido nas calotas polares e geleiras; $22,4 \%$ estão armazenados como água subterrânea; $0,35 \%$ formam os lagos e os pântanos; $0,04 \%$ permanecem na atmosfera, e $0,01 \%$ forma os rios. Toda a água doce da Terra disponível em rios e lagos equivale a $0,36 \%$ do total e representa um cubo de $52 \mathrm{~km}$ de aresta, número que se inclui em uma ordem de grandeza perfeitamente imaginável.

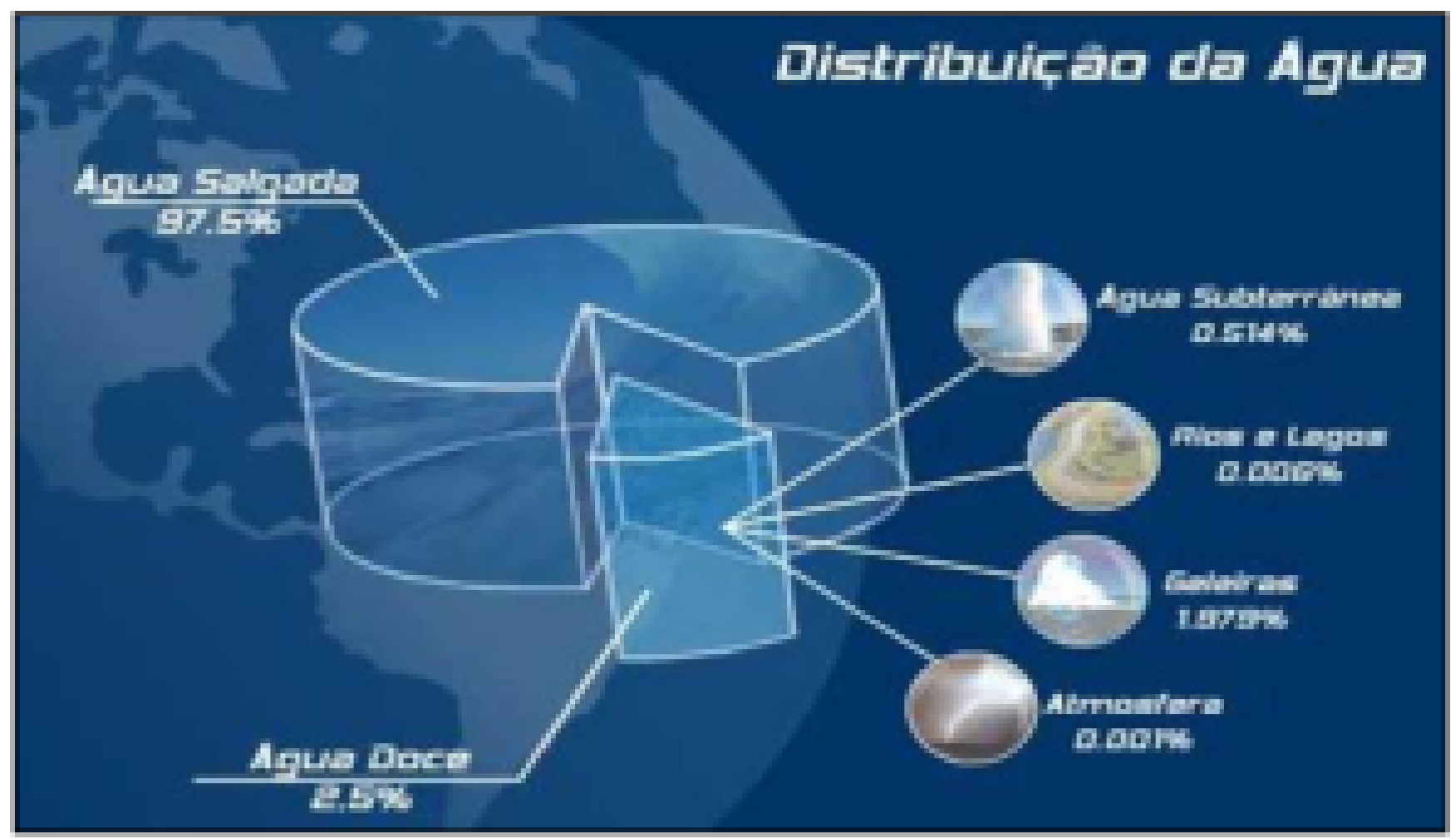

Figura 01 - Disposição da distribuição da água no planeta.

CRISE AMBIENTAL OU CRISE CIVILIZATÓRIA? 
Para uns, a maior parte dos problemas atuais pode ser resolvida pela comunidade científica, pois confiam na capacidade da humanidade produzir novas soluções tecnológicas e econômicas a cada etapa, em resposta aos problemas que surgem, permanecendo basicamente no mesmo paradigma civilizatório dos últimos séculos. Para outros, a questão ambiental representa quase uma síntese dos impasses que o atual modelo de civilização acarreta, pois consideram o que se assiste no final do século XX, não só como crise ambiental, mas civilizatória, e que a superação dos problemas exigirá mudanças profundas na concepção de mundo, de natureza, de poder, de bem-estar, tendo por base novos valores (ALFONSIN, 2001).

Faz parte dessa nova visão de mundo a percepção de que o ser humano não é o centro da natureza, e deveria se comportar não como seu dono, mas percebendo-se como parte dela, e resgatar a noção de sua sacralidade, respeitada e celebrada por diversas culturas tradicionais antigas e contemporâneas.

Chega-se a um ponto em que, indústria nos dias atuais tem que andar lado a lado com a integração ambiental e suas responsabilidades, ser uma indústria é ter responsabilidades sociais, seja a nível local, nacional e principalmente internacional, infelizmente há tempos teve-se uma visão predominante da Natureza como fonte de recursos para geração de riquezas e atendimento de necessidades antrópicas, que provocou graves impactos ambientais, cidadão transformado apenas em consumidor e usuário, porém, mediadas são adotadas a cada dia que passa a cada encontro sobre desenvolvimento e sustentabilidade, ter um objetivo hoje é fundamental na visão socioeconômico industrial, para que cheguem a um denominador comum respeitos aos protocolos da vida e principalmente na busca da qualidade de vida a todos. Mas, como gerir em ambiente em que, a atividade econômica e a herança social distribuem os homens desigualmente no espaço, produzindo desigualdades sociais, desigualdades territoriais, refletem, produzem e reforçam desigualdades sociais, com forte influência na cidadania e qualidade de vida (ALFONSIN, 2001).

Precisa-se primeiramente saber ter uma gestão nas mudanças sociais e quebrar paradigmas existentes dentro de nós seres humanos, acompanhar as mudanças tecnológicas de forma minimizar os estragos realizados pelas indústrias há séculos e aí sim, agir dentro da conscientização ambiental que se busca tanto.

É dessa forma que se inicia um parêntese dentro da indústria de produção de cerveja, de uma simples ideia as inovações tecnológicas e o passo a frente das questões ambientais. Mas, como lidar com mudanças não somente de gestão industrial, mas sim da gestão de pessoas, de pensamentos, a Teoria do Desenvolvimento Organizacional (DO) surgiu a partir de 1962, decorrente das ideias de vários autores, a respeito do ser humano, da organização e do ambiente em que estes crescem e se desenvolvem, o conceito de Desenvolvimento Organizacional está intimamente ligado aos conceitos de mudança e de capacidade adaptativa à mudança, portanto, nessa visão de mudanças que a indústria de cervejaria CERPASA-PA segue um rumo em que estão locados grandes indústrias nacionais e multinacionais.

Não adianta simplesmente ter a ideia de mudar ou se adaptar as questões socioambientais ou que envolvam tais questões, e sim ter atitude não somente da empresa em si, mas de todos que compõem, não basta ter mudanças e criar projetos sociais voltado ao meio ambiente e sim ter atitudes reais que, em um mercado competitivo é exigido. Para tanto, buscou-se entender como se da o processo industrial dentro da indústria de bebidas, especificamente da cervejaria paraense CERPASA e, como essa indústria de bebidas esta lidando com as mudanças ocorridas dentro de um mercado tão competitivo e rigoroso sobre as 
questões ambientais e uso dos recursos hídricos.

\section{A INDÚSTRIA DE CERVEJARIA CERPASA}

A indústria de cerveja Cerpa nasceu em 1966 pelas mãos da CERPASA ou Cervejaria Paraense como também é conhecida, através de dois estudantes um alemão e outro indiano, após chegarem ao Brasil e ter feito um negócio em uma indústria de pesca no Rio de janeiro, projeto esse que não foi a frente. Após a primeira experiência não agradável, os dois estudantes de ideias e projetos grandes, conheceram um paraense que indicou e falou sobre o estado do Pará, aonde os mesmos vieram e montaram após rigorosos estudos da região e principalmente dos recursos naturais em especial o recurso hídrico, uma fábrica de cervejaria. A fabrica fica instalada junto das margens da Baía do Guajará, em Belém - PA, em uma área de $157.633 \mathrm{~m}^{2}$, recebeu o titulo de pioneirismo na região como primeira cervejaria. Apesar da forte concorrência de produtos de outras cervejarias como a Brahma e a Antarctica, a Cerpa com um dos parques industriais de cervejaria mais avançados do Brasil conseguiu granjear um bom prestígio a nível interno.

Procurando diferenciar-se das suas rivais pela qualidade do produto e inovação, a Cerpa apresentou, em 1996, o processo Draft Beer, no qual a cerveja não passa pelo tradicional sistema de pasteurização, mas antes por uns complexos filtros de celulose e descarga térmica. Hoje a indústria comporta em seu quadro de trabalhadores 330 funcionários diretos, além dos mais de mil outras pessoas que trabalham indiretamente, seja com depósitos de distribuição de bebidas, quanto os pontos de venda direta ao consumidor, com uma linha de pensamento sempre inovador e a frente de questões ambientais. 


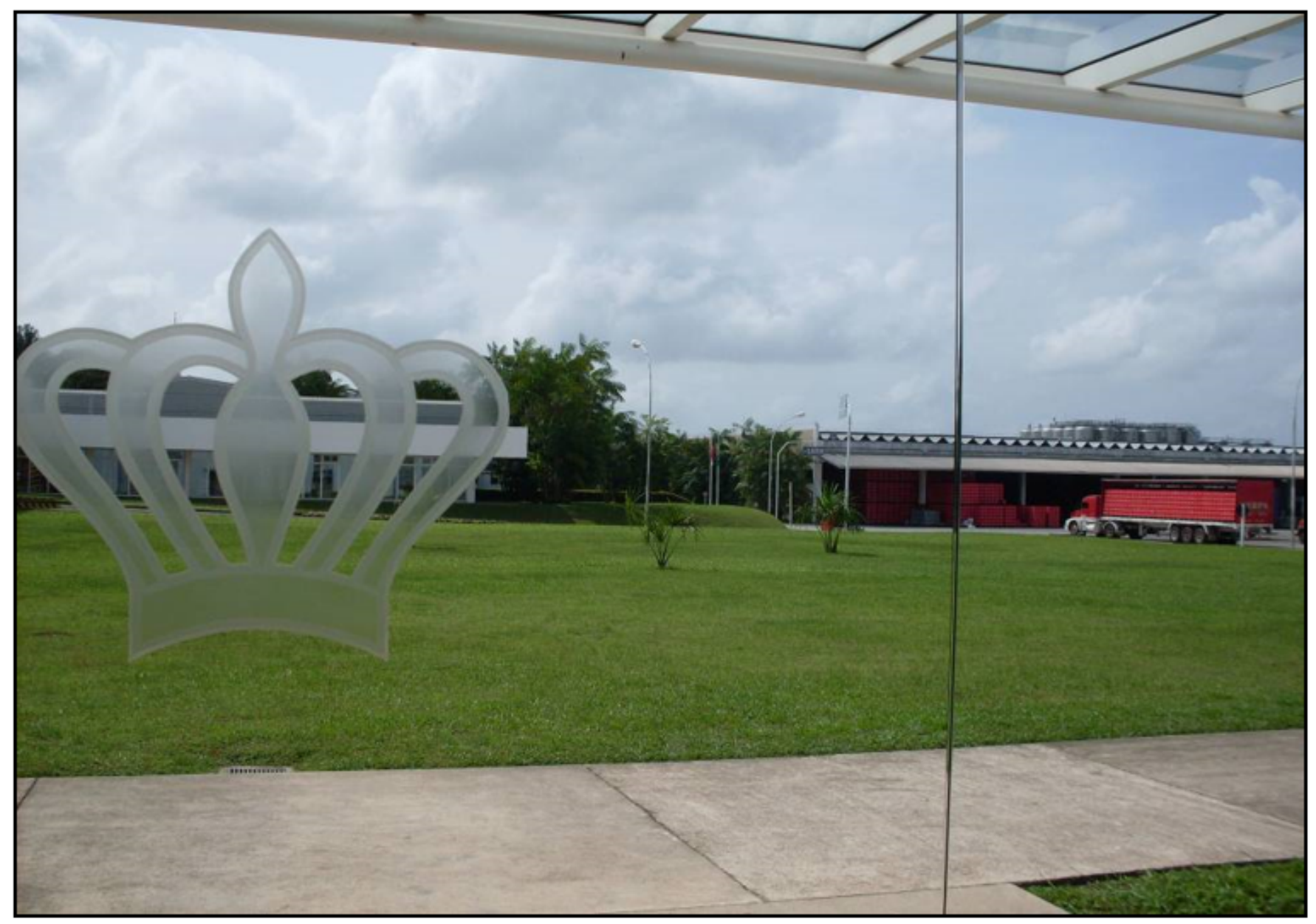

Figura 04 - Imagem do parque industrial de bebidas da CERPASA.

Como citado anteriormente dentro deste artigo, educação ambiental não é simplesmente cuidar de lixo ou preservar algum meio ambiente, mas sim mudar atitudes em que envolvam todos. Dentro da CERPASA trabalham-se questões ambientais e tecnologias, antes até surgir tais discussões sobre meio ambiente, sustentabilidade, educação ambiental, desenvolvimento sustentável, trabalha-se não somente o como mudar ou se adaptar, mas como inovar e se antecipar as tais mudança que ocorrem dentro do mercado industrial. Daí que, identificou-se como se precedem as questões ambientais: Educação Ambiental e Uso dos Recursos Hídricos, dentro da indústria de cervejaria: CERPASA.

A CERPASA hoje trabalha as questões ambientais, desde a sua adequação ao exigente mercado consumidor, até trabalhos sociais dentro da própria empresa junto aos funcionários, dando acima de qualquer coisa, uma qualidade de vida tanto dentro, quanto fora da empresa. Parte-se da linha de produção da cervejaria que, há um reaproveitamento do descarte da água utilizado no processo de produção de suas bebidas, trabalho com o descarte do lúpulo na produção da cerveja, compra de madeira para alimentação das caldeiras, todas legalizadas e autorizadas pelo IBAMA, reaproveitamento do descarte de garrafas e latas, para locais de coletas adequados no reaproveitamento de tais produtos, avisos em toda a fábrica, no que diz respeito à educação ambiental, harmonização da indústria em si com o meio ambiente, tentando buscar não modificar a paisagem desde sua fundação. Inicia-se fato de pesquisa sobre o uso dos recursos hídricos dentro da CERPASA. 
Hoje a fábrica de bebidas possui um extremo rigor na qualidade do uso de seu recurso hídrico para a fabricação de seus produtos, apesar de se encontrar as margens da Baía do Guajará, a mesma possui dentro de seu terreno três poços de captação do recurso hídrico, com aproximadamente em sua metragem de $350 \mathrm{~m}$ de profundidade, onde após captação do recurso hídrico, o mesmo recebe tratamento para purificação e retirada de alguns minerais em excesso na água (ferro). Seguindo o processo de captação, purificação aí sim o mesmo é utilizado na linha de produção de bebidas, o recurso hídrico é de tal importância que é utilizado também dentro da própria fábrica para outras tarefas, como lavagem dos veículos, roupas dos funcionários, preparação de alimentos, utilização para o consumo e de limpeza em geral. Pelo que foi pesquisado a fábrica não utiliza recuso hídrico da rede de abastecimento do Estado (COSAMPA). Segue algumas imagens do processo citado anteriormente na utilização do recurso hídrico dentro da indústria de cervejaria.

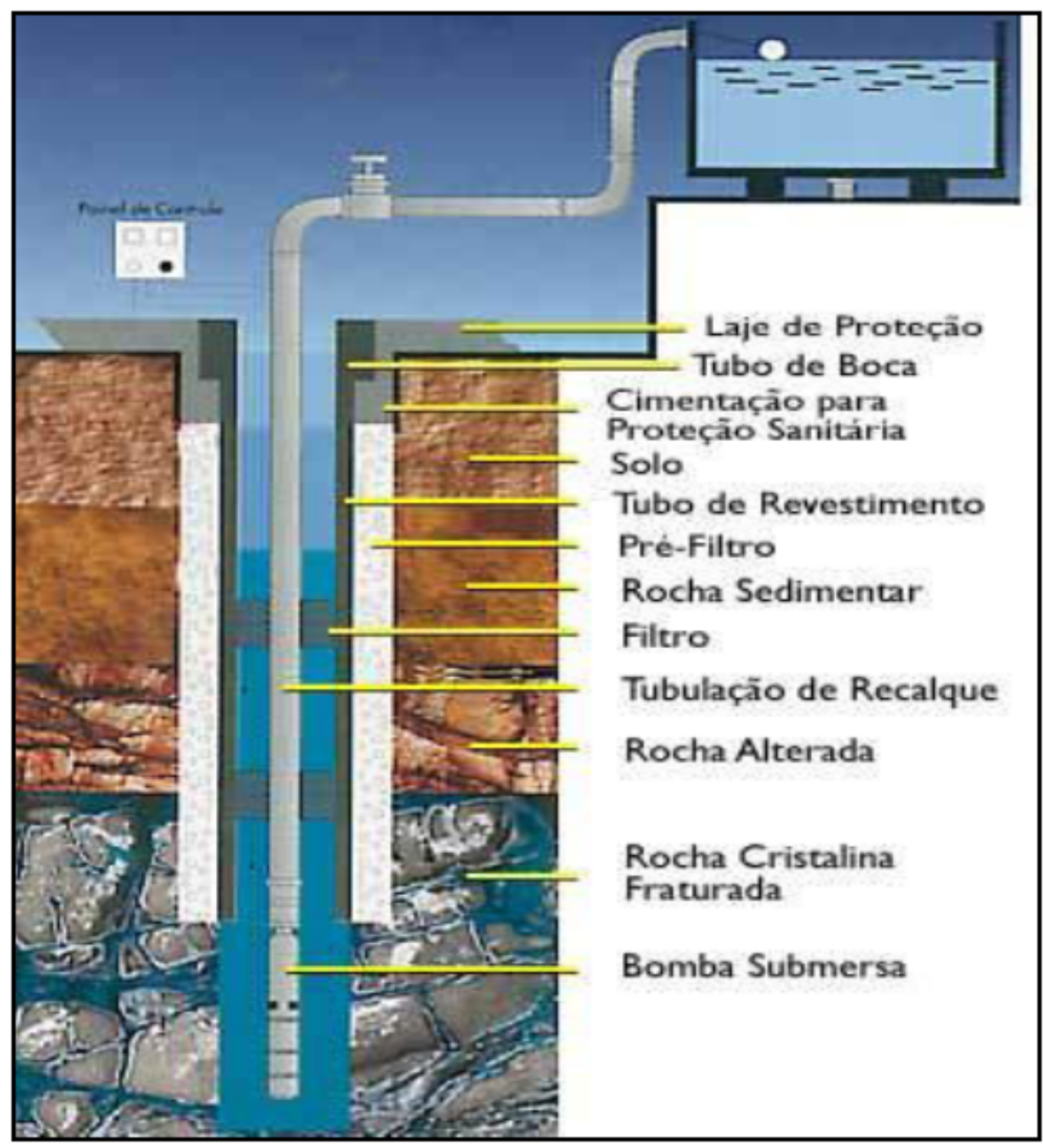

ilustrativa da formação de um poço de captação de recurso hídrico. 
Revista Científica Multidisciplinar Núcleo do Conhecimento - RC: 1323 - ISSN: 2448-0959

https://www.nucleodoconhecimento.com.br/geografia/recursos-hidricos

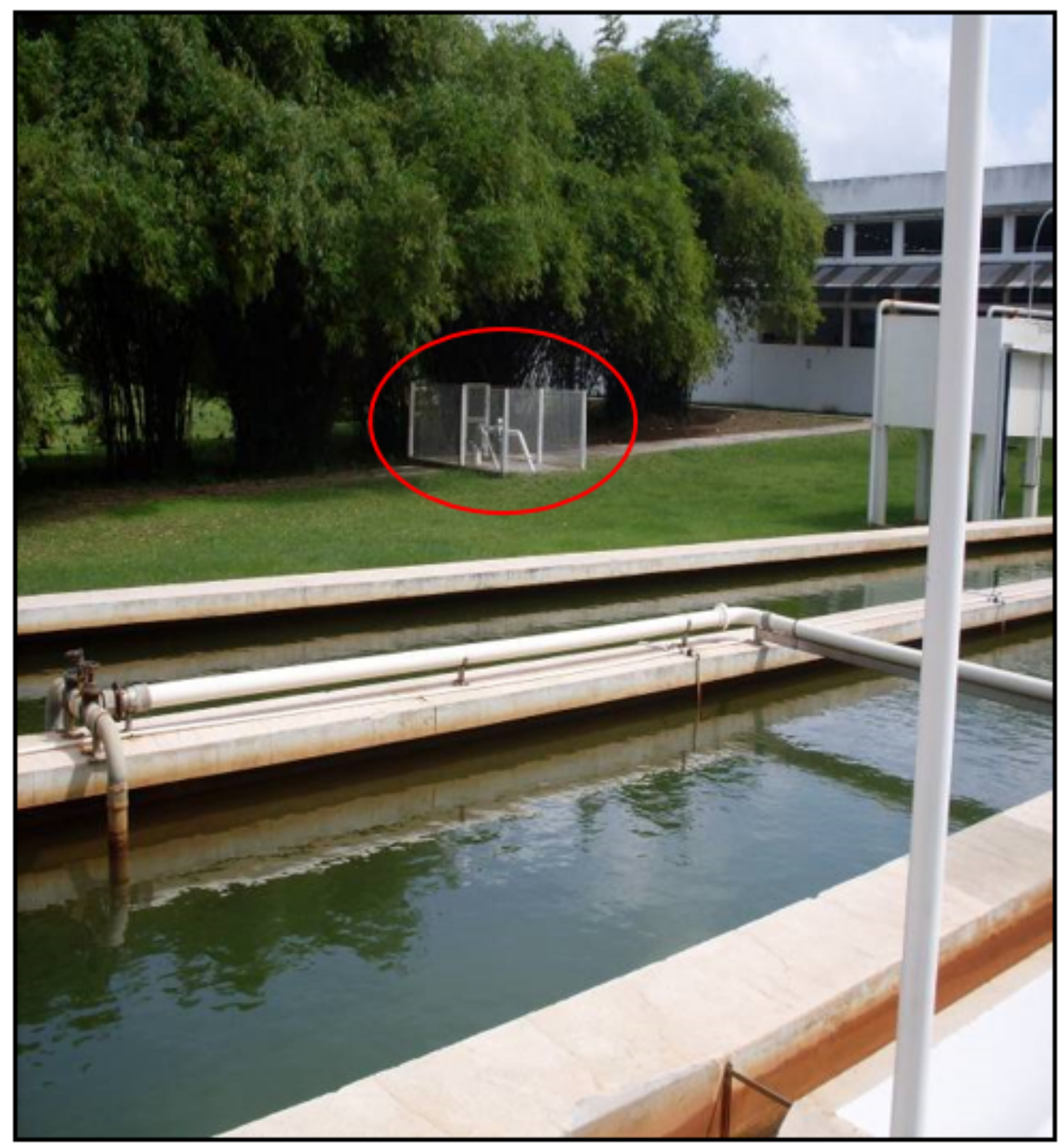

Figura 06 - Imagem em destaque do poço de captação do recurso hídrico, dentro parque indústria de bebidas CERPASA. 
Revista Científica Multidisciplinar Núcleo do Conhecimento - RC: 1323 - ISSN: 2448-0959

https://www.nucleodoconhecimento.com.br/geografia/recursos-hidricos

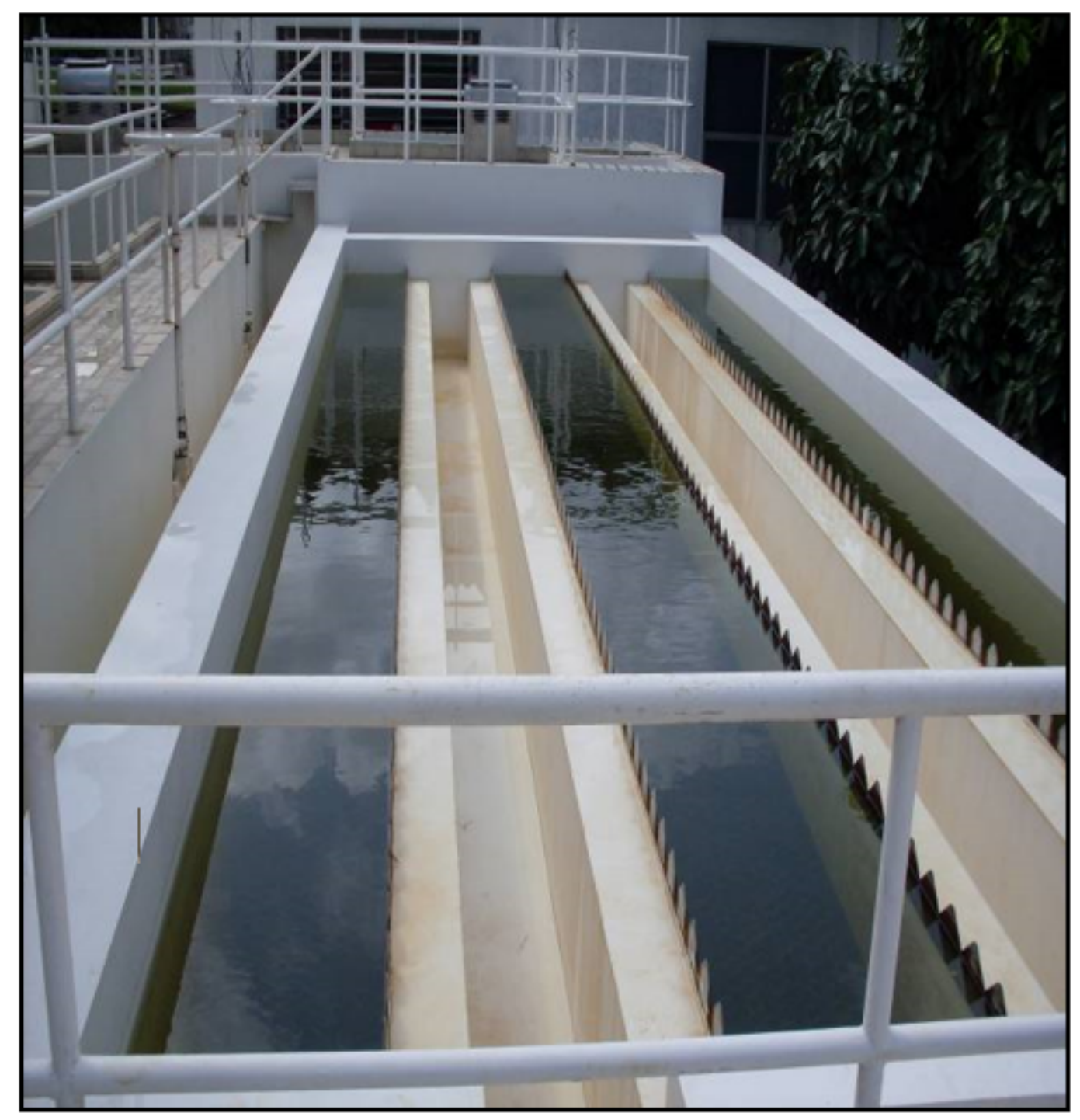

Figura 07 - Imagem

do tanque de tratamento da água utilizado na produção da CERPASA. 


\section{Revista Científica Multidisciplinar Núcleo do Conhecimento - RC: 1323 - ISSN: 2448-0959}

https://www.nucleodoconhecimento.com.br/geografia/recursos-hidricos

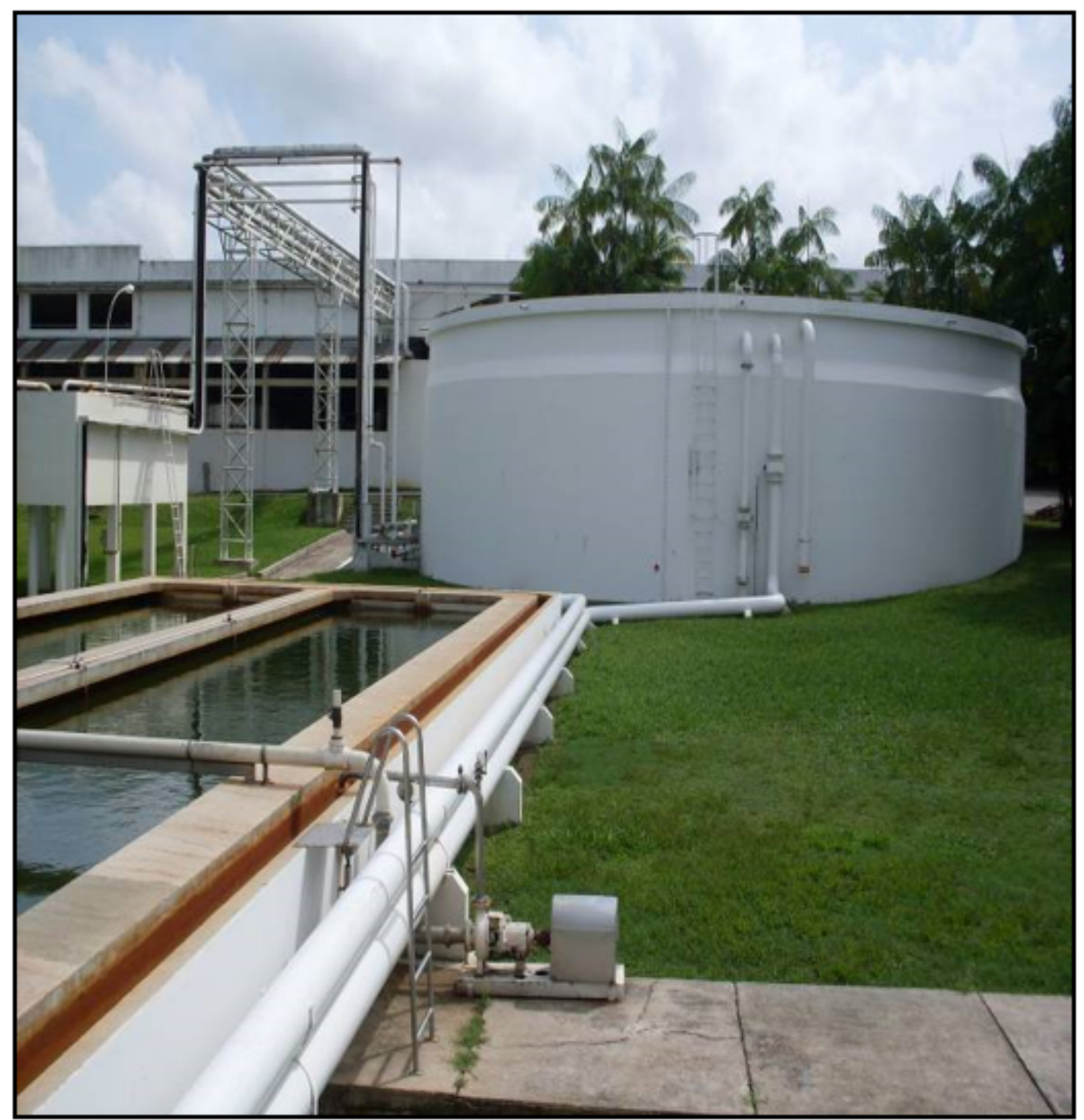

Figura $08 \quad-$

Imagem do tanque onde fica o produto final antes da utilização da água no processo de fabricação de bebidas CERPASA

Esse é o processo da água tratada: Após a captação, a água sofre transformações durante o seu tratamento para se adequar aos usos previstos (exemplo: industrial na produção de bebidas). Parte desse recurso hídrico é utilizado na produção das bebidas e outra parte na linha de produção como, lavagem das garrafas, retiradas de rótulos e impurezas, quase que totalmente mecanizado, as maquinas de produção dependem de uma grande quantidade de água, visto nas imagens seguintes. 
Revista Científica Multidisciplinar Núcleo do Conhecimento - RC: 1323 - ISSN: 2448-0959

https://www.nucleodoconhecimento.com.br/geografia/recursos-hidricos

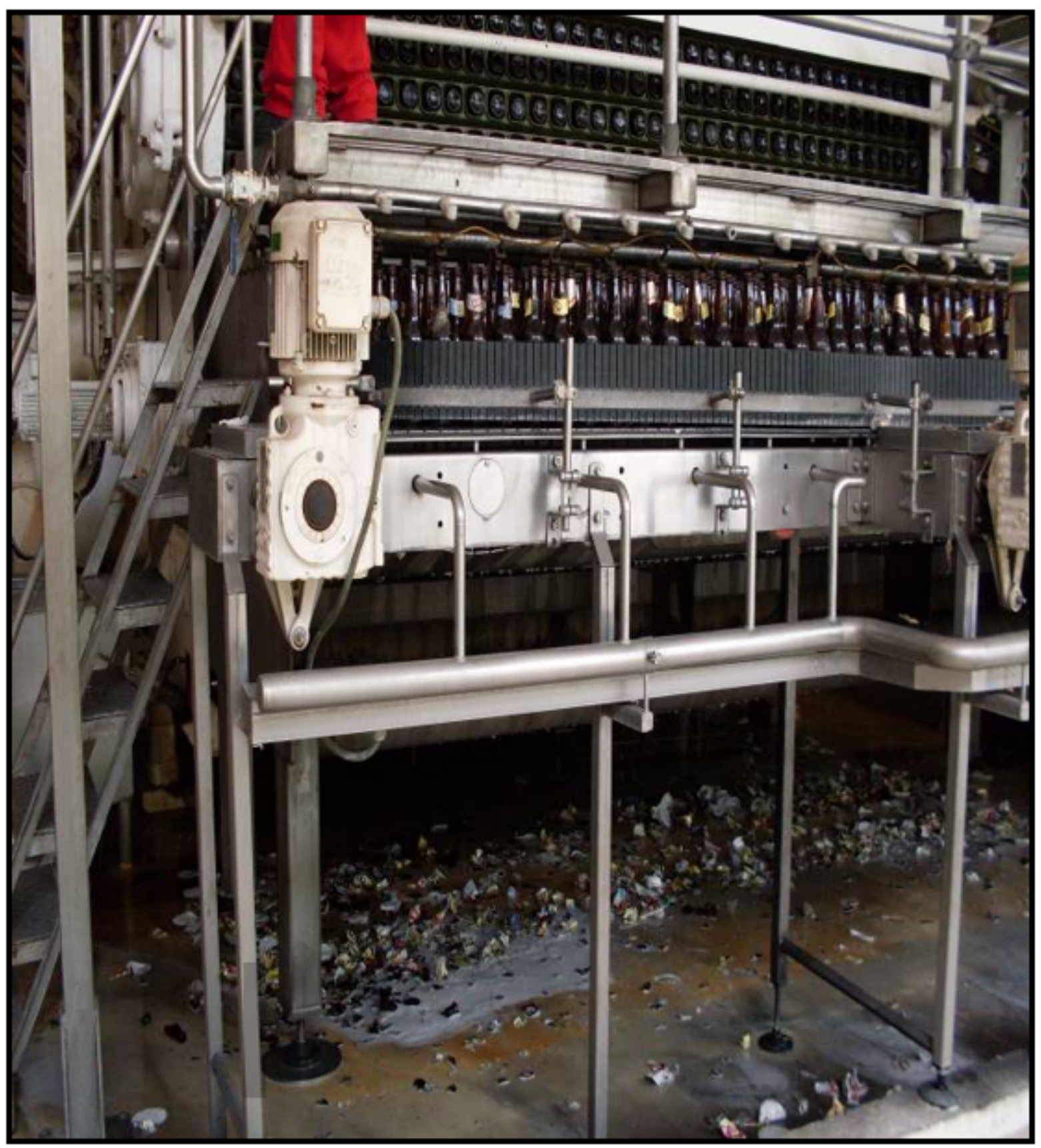

- Imagem da linha de produção da CERPASA parte de limpeza das garrafas. 
Revista Científica Multidisciplinar Núcleo do Conhecimento - RC: 1323 - ISSN: 2448-0959

https://www.nucleodoconhecimento.com.br/geografia/recursos-hidricos

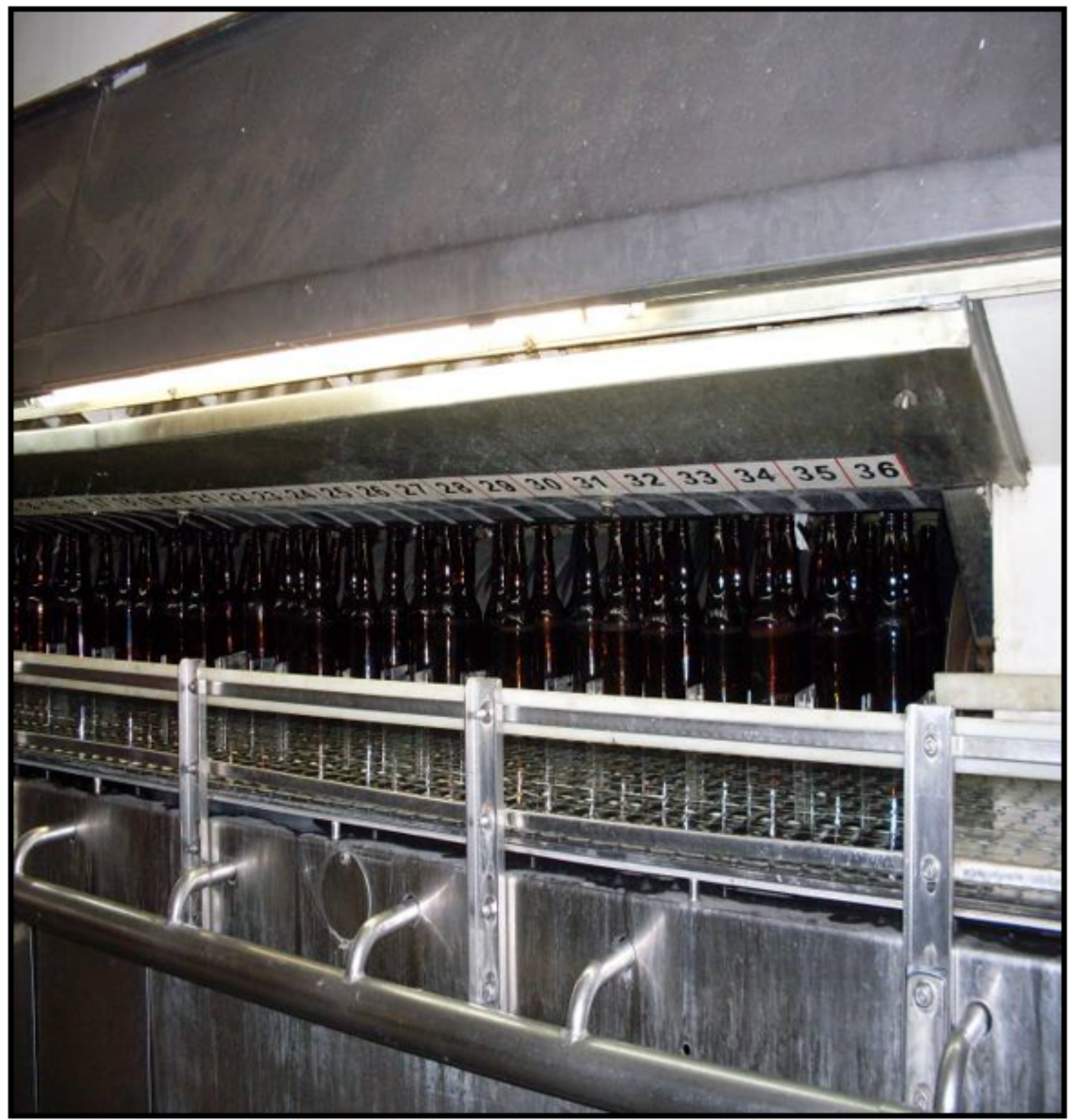

Figura

10 - Imagem da linha de produção da CERPASA parte de limpeza das garrafas. 
Revista Científica Multidisciplinar Núcleo do Conhecimento - RC: 1323 - ISSN: 2448-0959

https://www.nucleodoconhecimento.com.br/geografia/recursos-hidricos

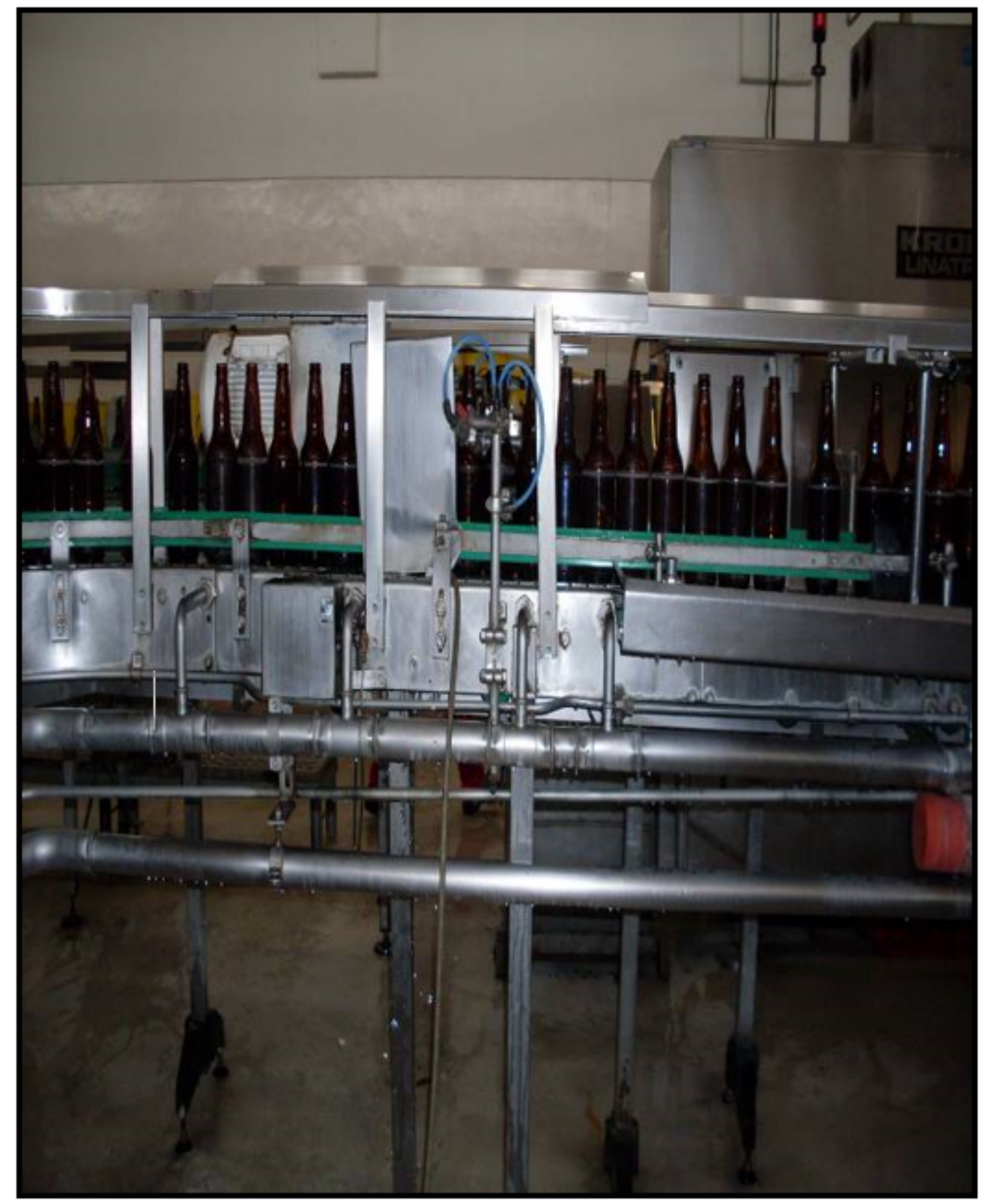

Imagem da linha de produção da CERPASA parte de limpeza das garrafas.

Figura $11 \quad-$ 


\section{Revista Científica Multidisciplinar Núcleo do Conhecimento - RC: 1323 - ISSN: 2448-0959}

https://www.nucleodoconhecimento.com.br/geografia/recursos-hidricos

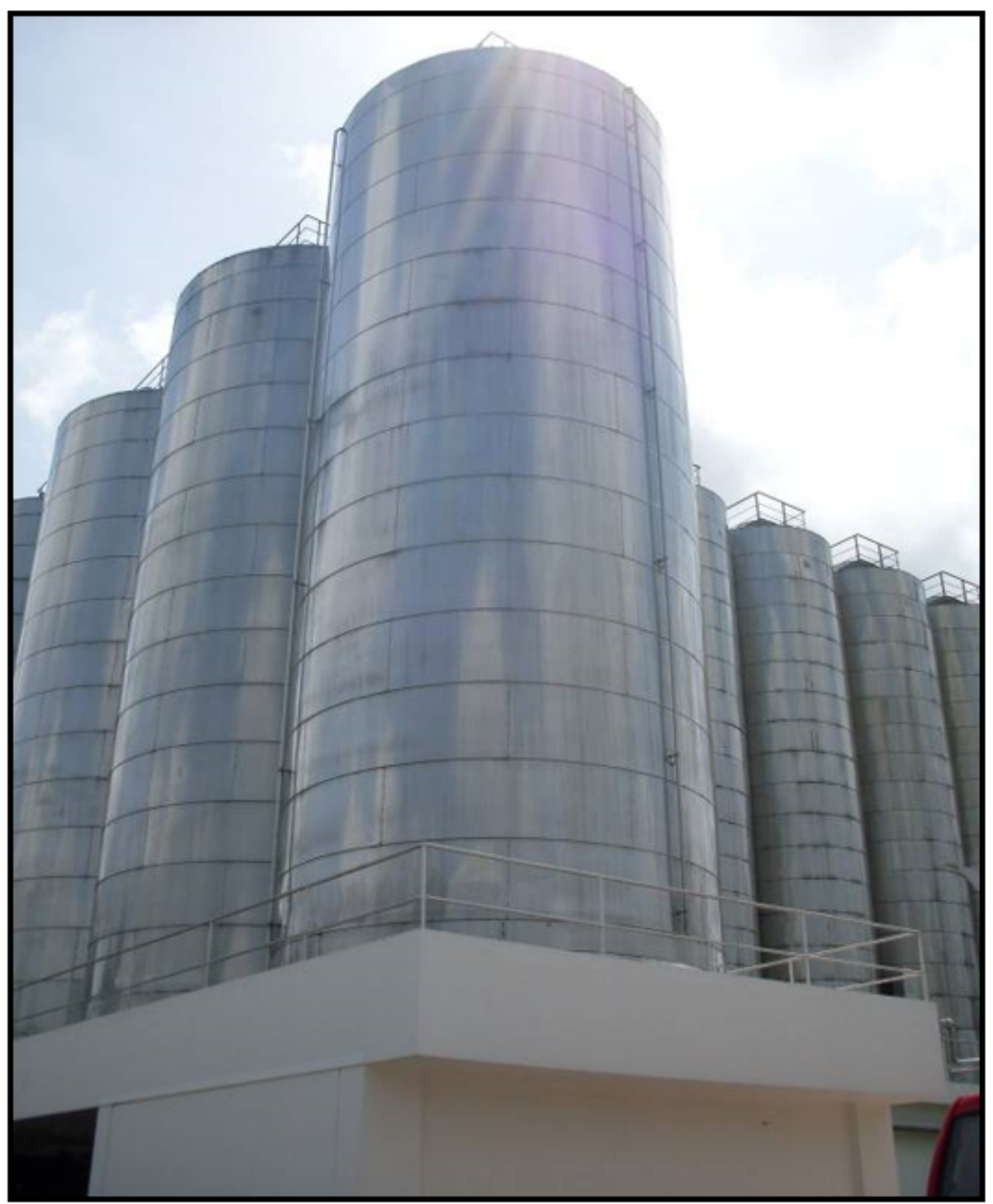

Figura $12-$

Imagem dos tanques onde ficam armazenados os ingredientes na preparação das bebidas na CERPASA.

A indústria de cervejaria CERPASA não se prende somente a captação e utilização de recursos hídricos em sua linha de produção de bebidas, há também um trabalho na preservação do meio em que a mesma está inserida, ou seja, tenta manter em sua área total, todo e qualquer corpo natural sem fazer grandes modificações desde sua fundação e será mostrado nas seguintes imagens. 


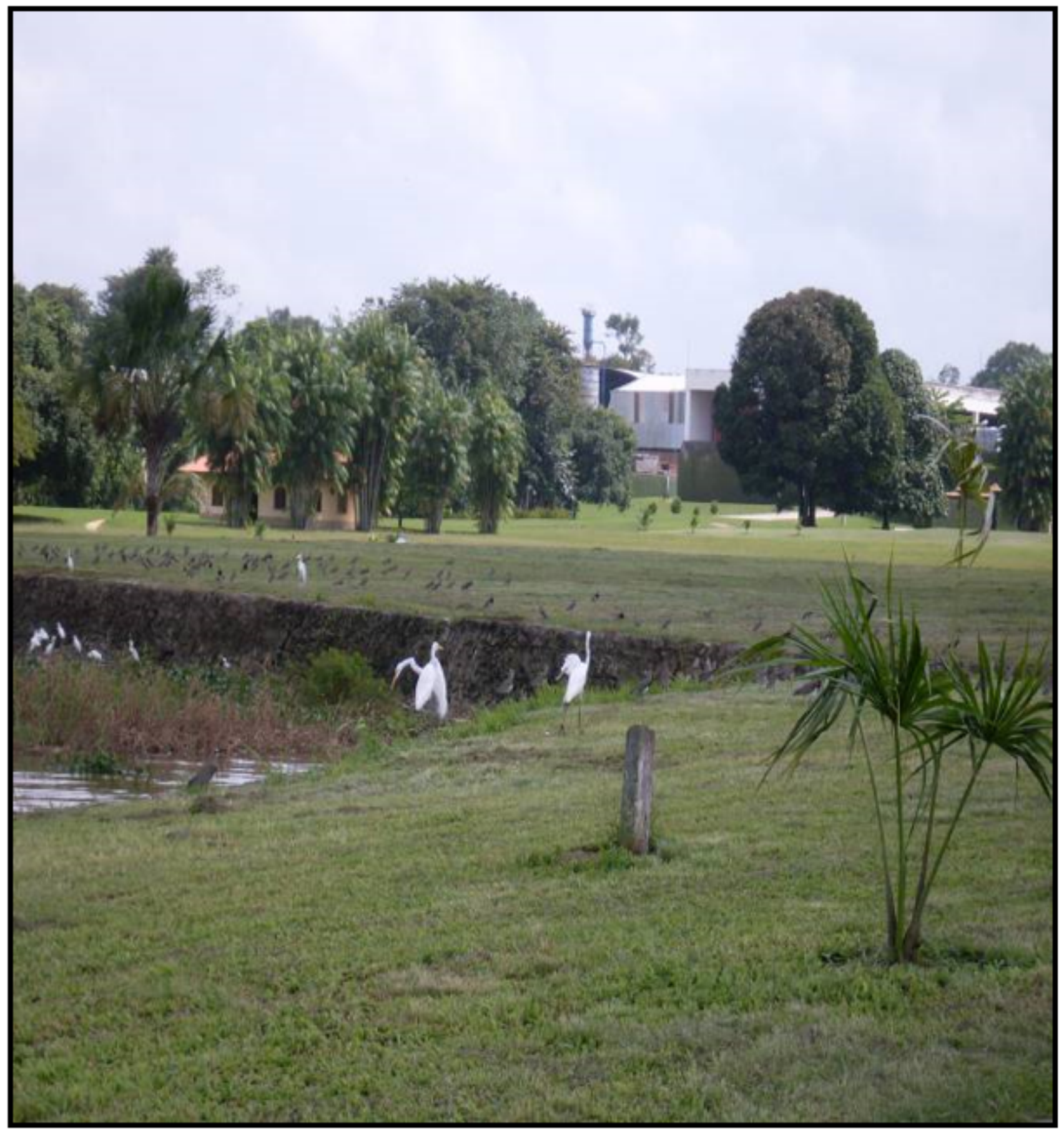

Figura 13 - Imagem do parque industrial de bebidas CERPASA, inserido dentro de um sistema o mais natural possível. 


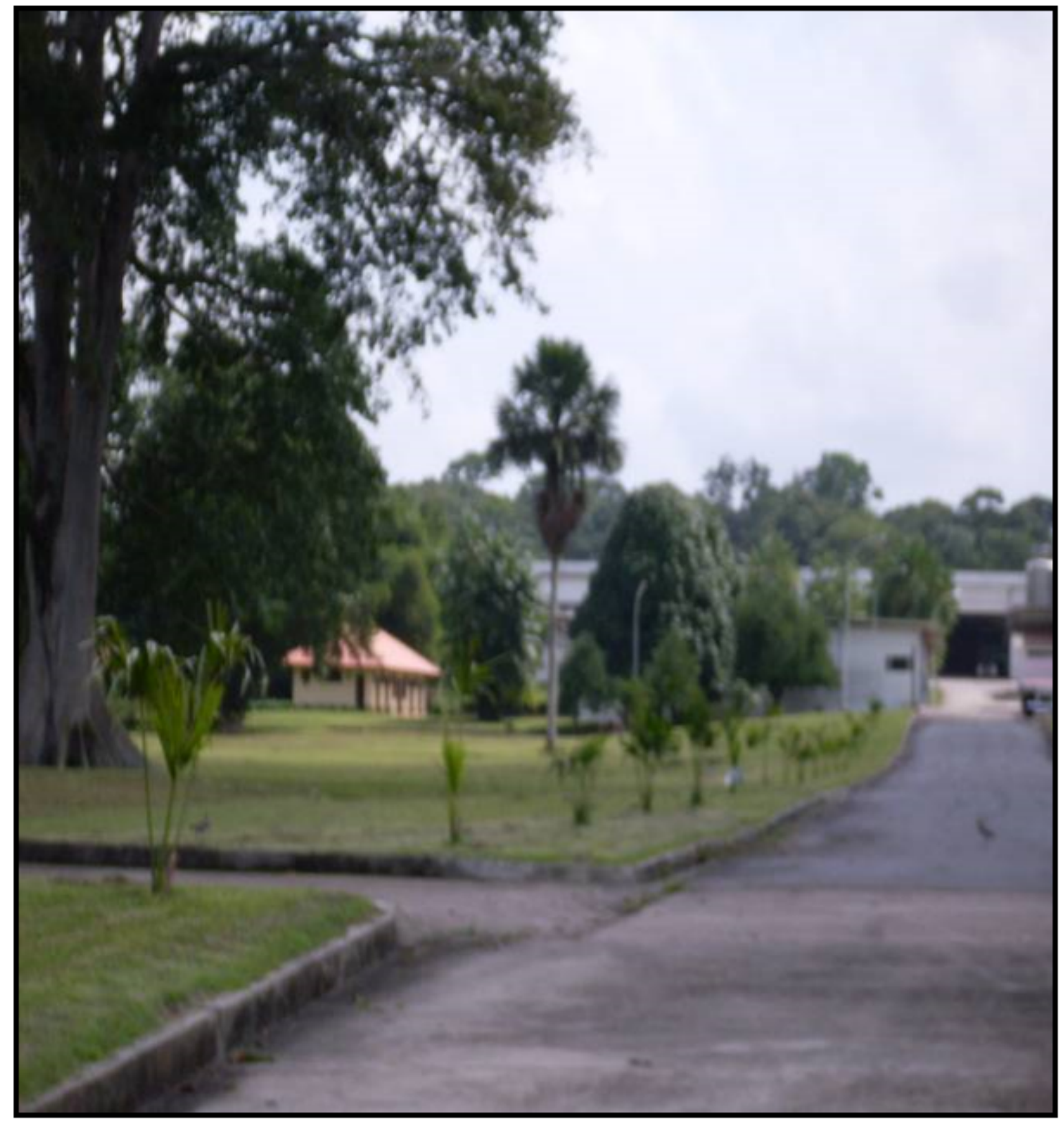

Figura 14 - Imagem do parque industrial de bebidas CERPASA, inserido dentro de um sistema o mais natural possível.

Ao analisar as consequências negativas, decorrente da falta da implementação de programa de educação ambiental dentro da indústria de cervejaria CERPASA, foi pesquisado o quanto seria despejado de insumos descartados da indústria no meio ambiente, produtos que em quase todo é reaproveitado ou beneficiado entes do descarte final. Temos a questão do tratamento do descarte dos recursos hídricos após passar pela linha de produção e também dos descartes de material sólido, o seguinte processo é: 
Revista Científica Multidisciplinar Núcleo do Conhecimento - RC: 1323 - ISSN: 2448-0959

https://www.nucleodoconhecimento.com.br/geografia/recursos-hidricos

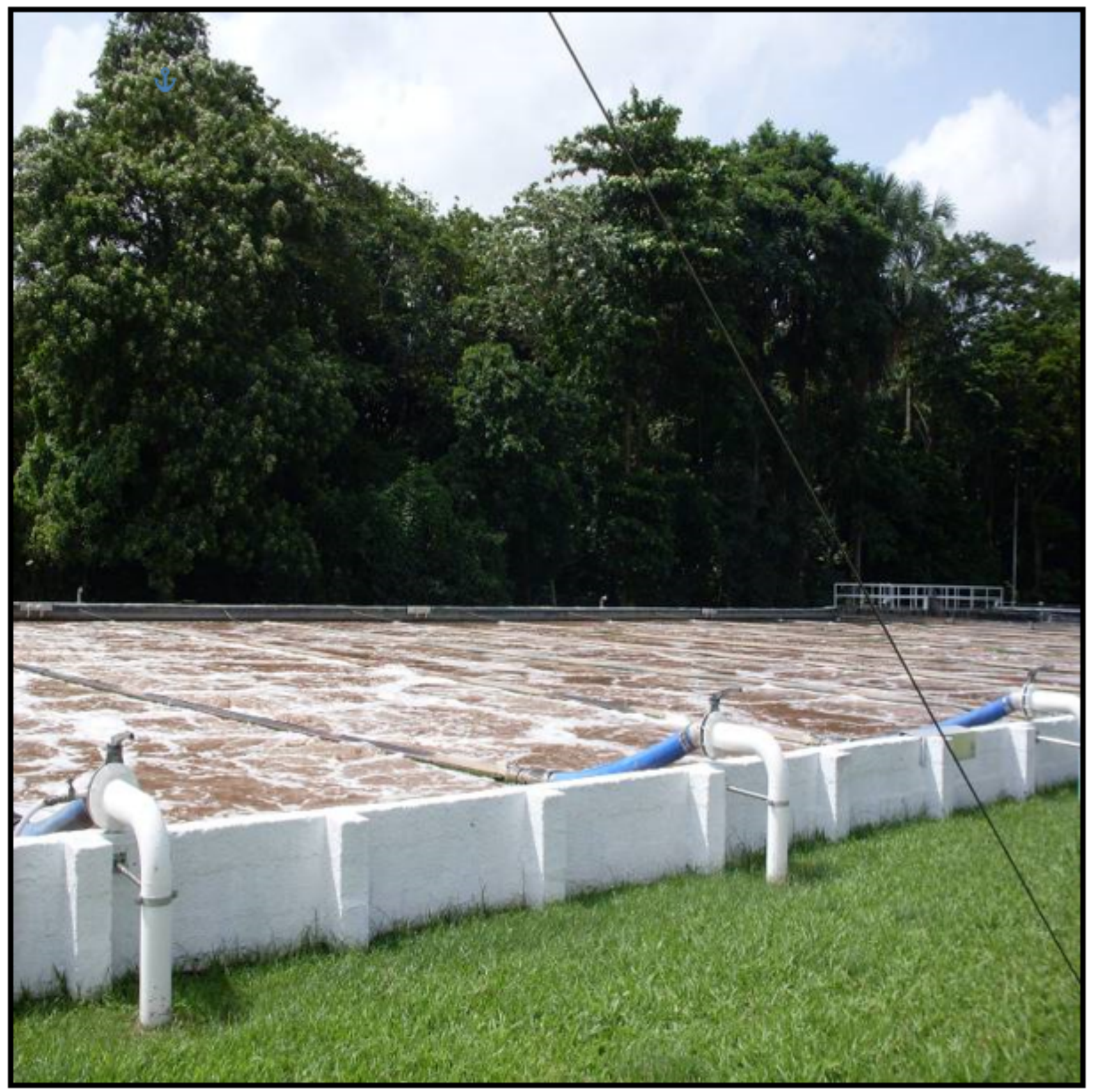

Figura 15 - Imagem do tanque de tratamento do descarte da produção de bebidas, onde ocorre a separação do liquido, sólido e gasoso da CERPASA. 


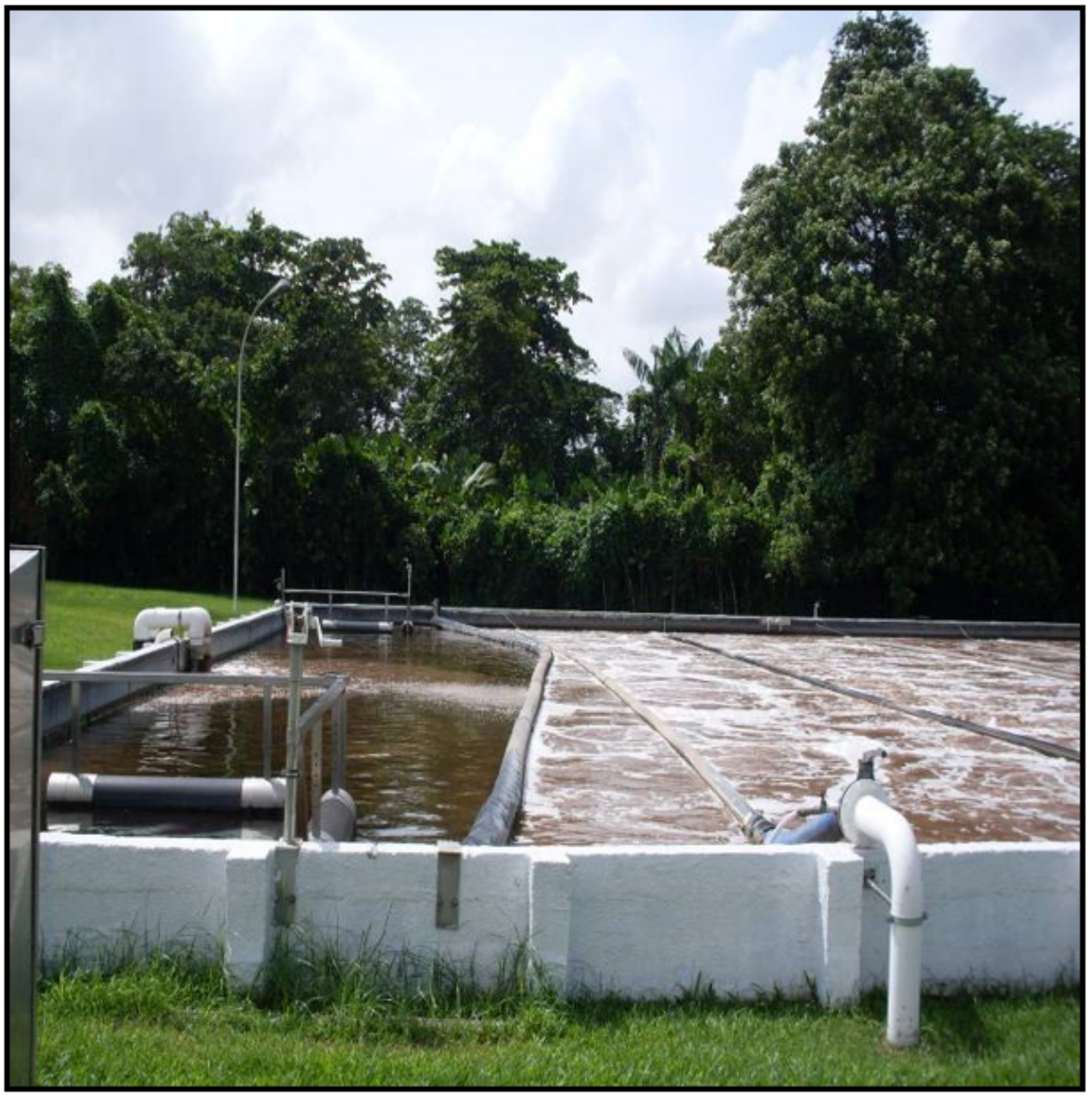

Figura 16 - Imagem do tanque de tratamento do descarte da produção de bebidas, ocorrendo à separação do liquido do sólido. 


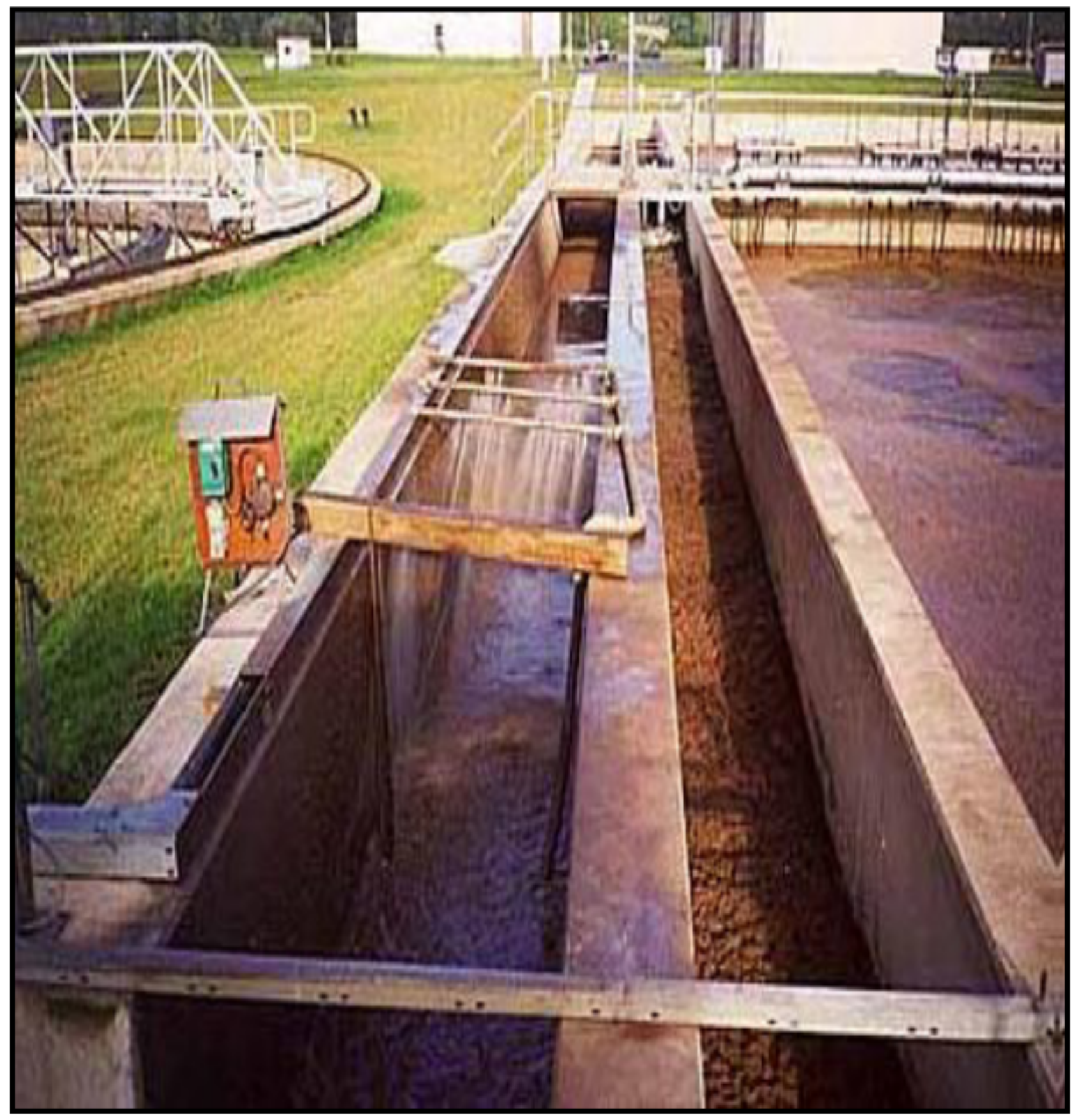

Figura 17 - Imagem do tanque de tratamento do descarte da produção de bebidas, ocorrendo à separação do sólido e do liquido. 


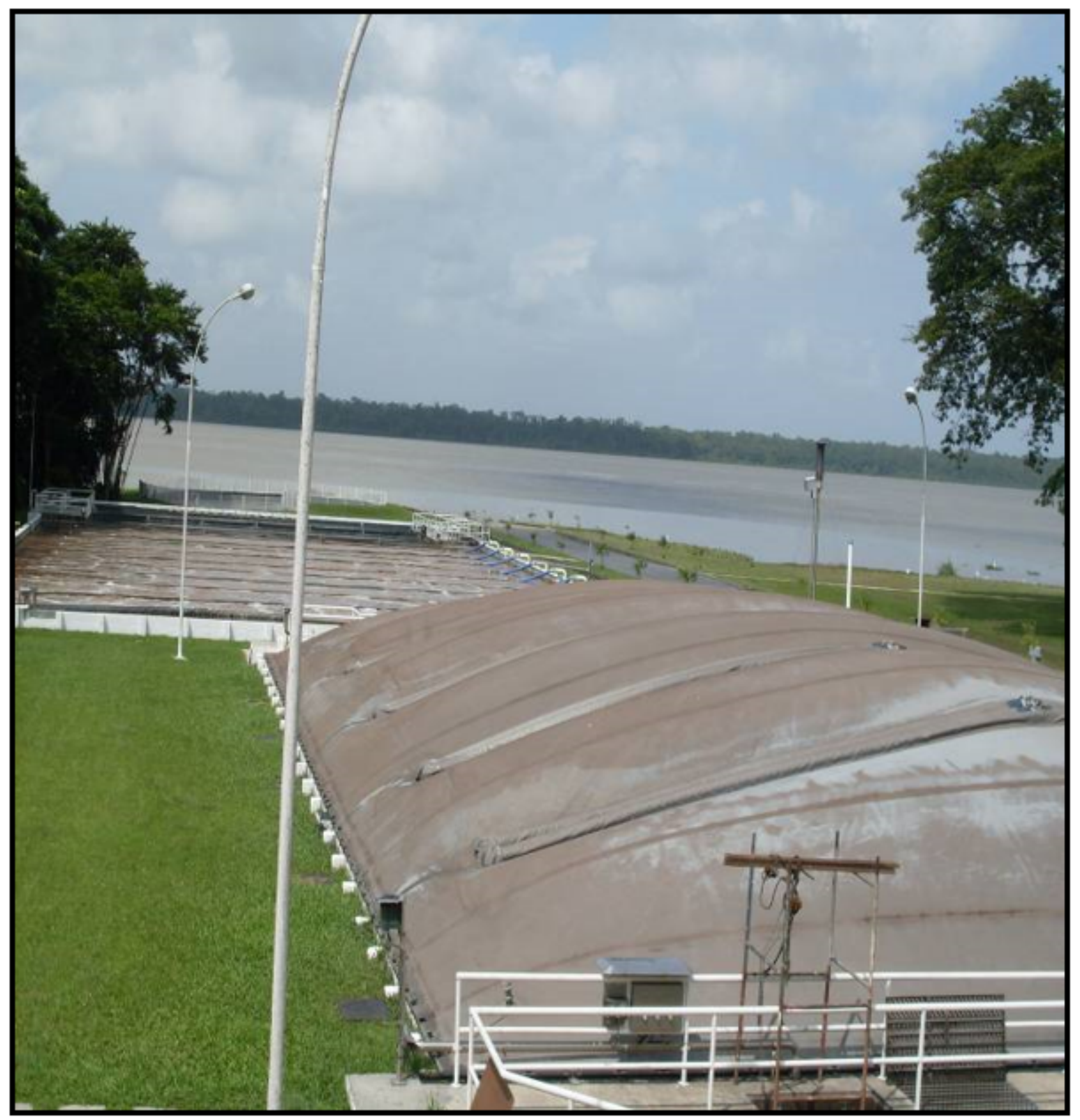

Figura 18 - Imagem do tanque de tratamento do descarte da produção de bebidas, ocorrendo à separação do gás, do sólido e do liquido.

Esse é o processo de descarte utilizado dentro da produção de bebidas, o processo como foi visto, consiste em três fases bem definidas, onde acontece o abastecimento de um tanque, ocorrendo à separação do gás, do liquido e do sólido que são descartados após passarem pela linha de preparação da indústria de cervejaria pesquisada, sendo que o ponto final é o descarte do recurso hídrico tratado e despejado dentro da Baía do Guajará, imagens a seguir: 
Revista Científica Multidisciplinar Núcleo do Conhecimento - RC: 1323 - ISSN: 2448-0959

https://www.nucleodoconhecimento.com.br/geografia/recursos-hidricos

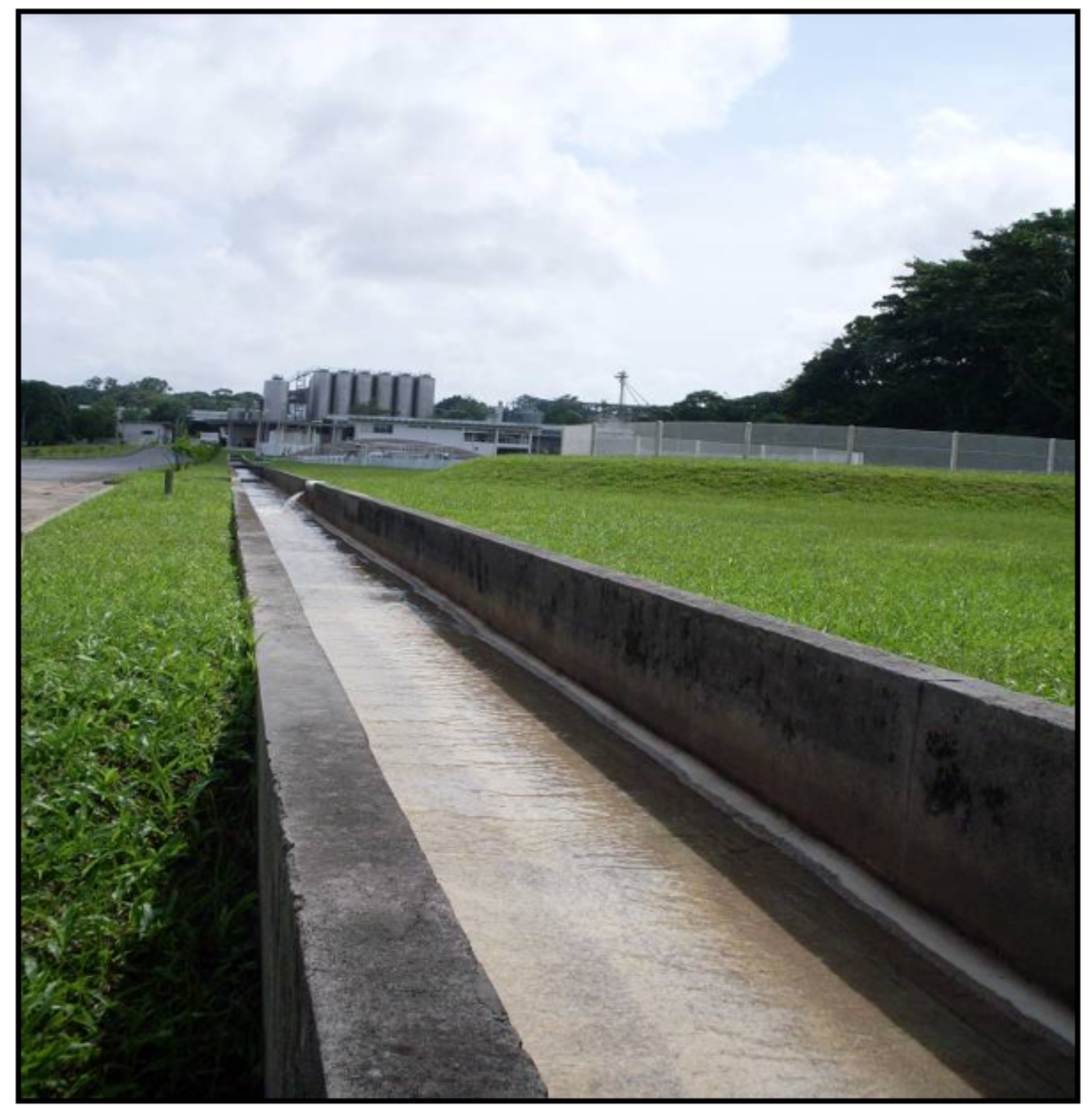

Figura 19 - Imagem da canaleta, onde é despejada a água tratada dentro da Baía do Gaujará. 


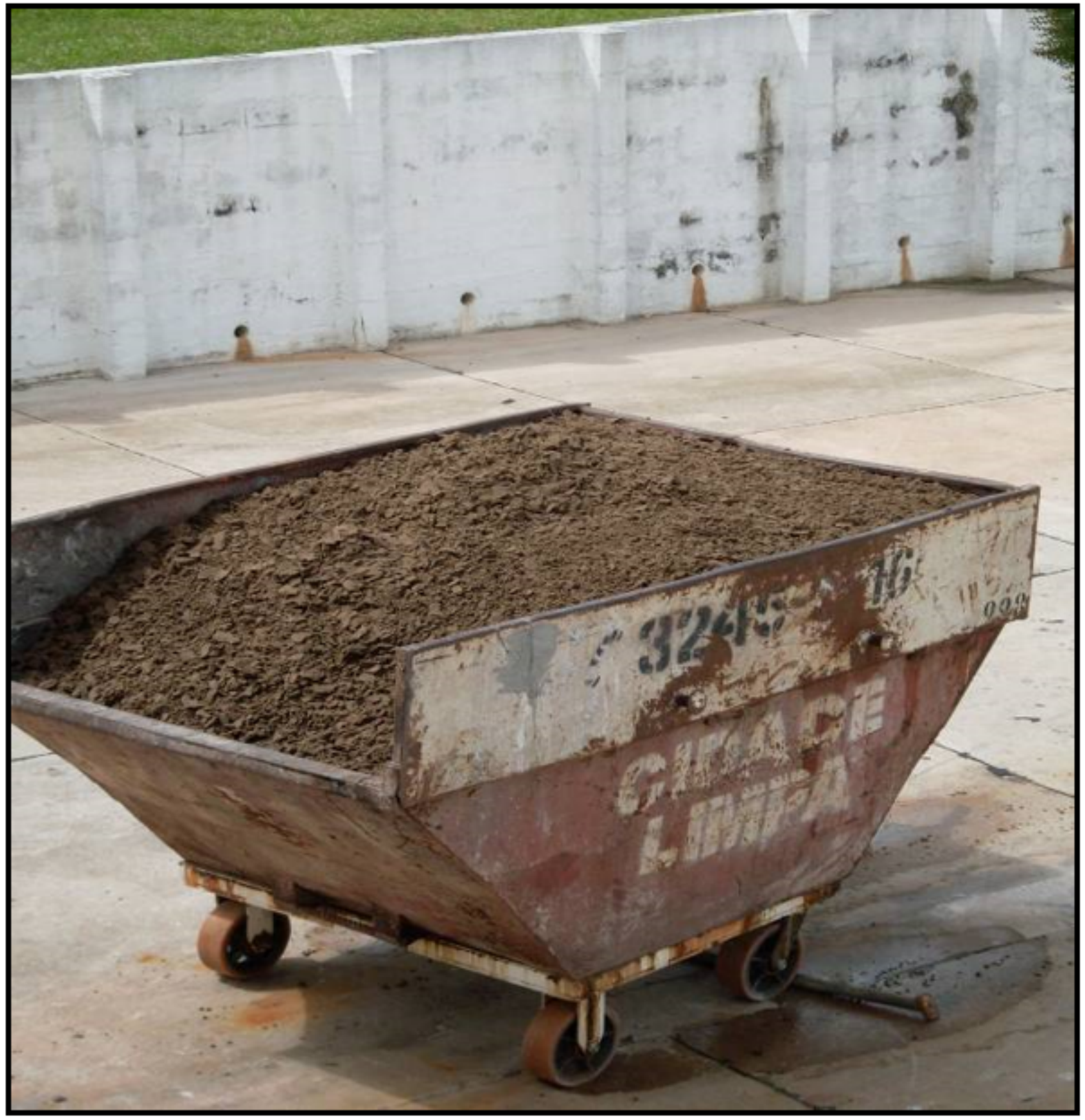

Figura 20 - Imagem do resíduo sólido após separação do mesmo dentro do tanque de separação do sólido, do liquido e do gás.

Outras atitudes foram implantadas para sair na frente de um mercado tão competitivo e tão rigoroso, imagina-se se não ocorresse tal procedimento dentro dessa indústria de cervejaria, o quanto seria absorvido de poluentes no seu estado bruto pela natureza. Trabalha-se também com outros agentes na cervejaria, não somente por parte da empresa em si, mas por parte de todos dessa empresa. Com tais implementações, ganhou-se em relações custo benefícios, tanto para empresa quanto ao meio ambiente, outras políticas socioambientais também fazem parte desse processo, como: 
Revista Científica Multidisciplinar Núcleo do Conhecimento - RC: 1323 - ISSN: 2448-0959

https://www.nucleodoconhecimento.com.br/geografia/recursos-hidricos

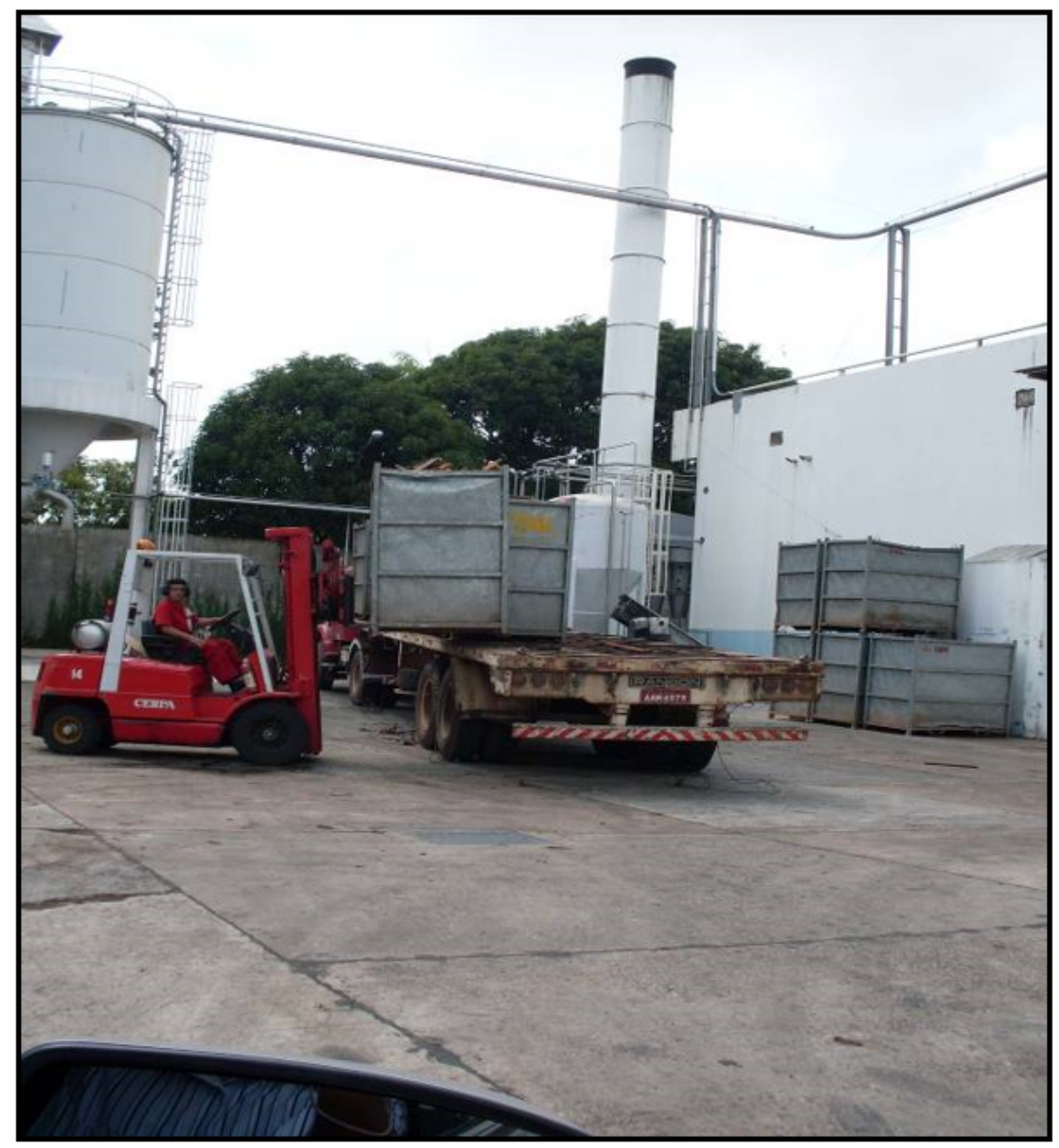

Figura 21 - Imagem do abastecimento das caldeiras com madeira autorizada pelo IBAMA. 


\section{Revista Científica Multidisciplinar Núcleo do Conhecimento - RC: 1323 - ISSN: 2448-0959}

https://www.nucleodoconhecimento.com.br/geografia/recursos-hidricos

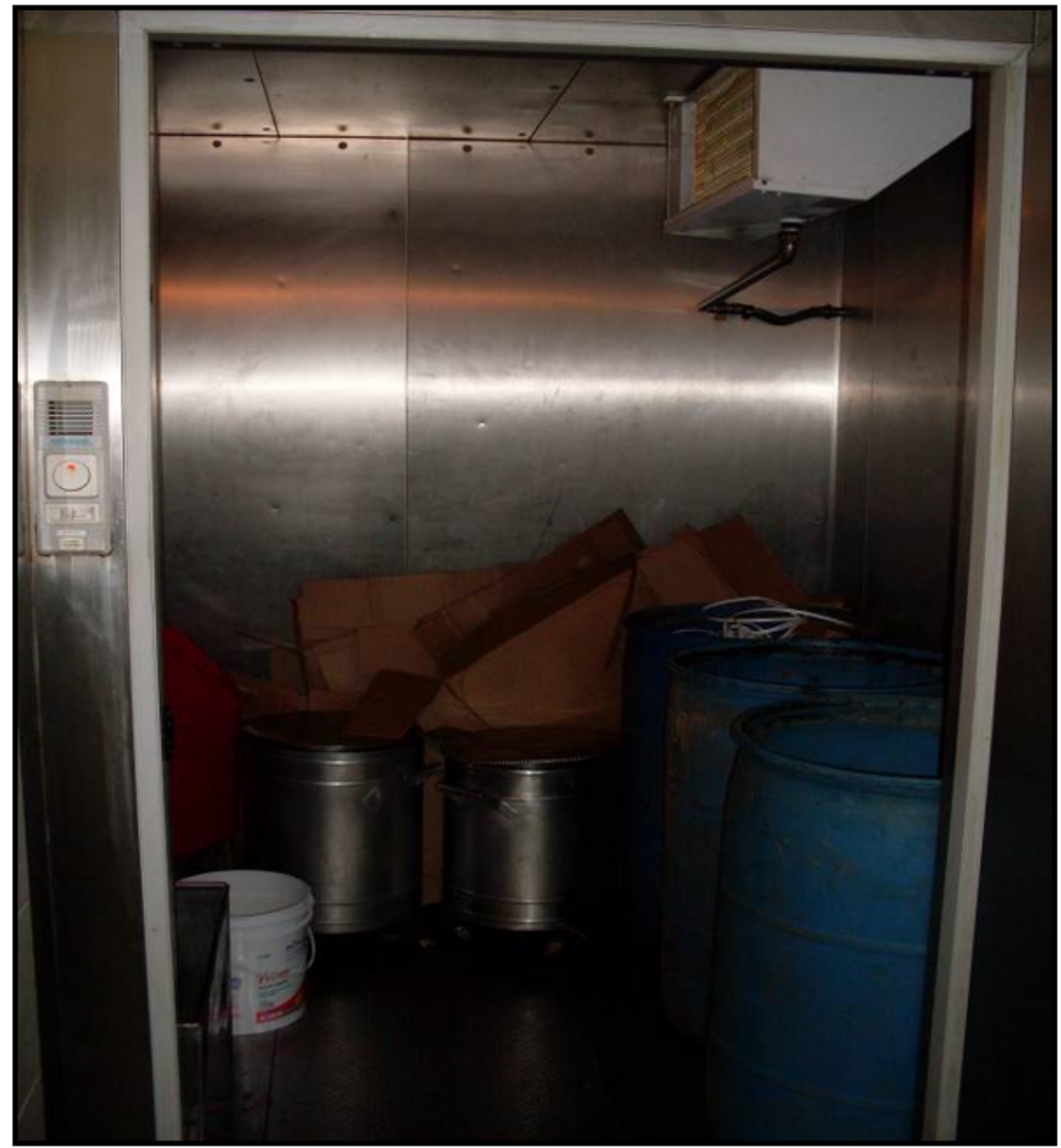

Figura 22 - Imagem da câmara de resfriamento de sobras de alimentos, para evitar proliferação de insetos ou bactérias.

Percebe-se que em indústria desse porte, nada será feito sozinho ou simplesmente apenas por parte da empresa, mas sim com a colaboração de todos, pois educação ambiental é a corresponsabilização dos indivíduos tornando-se um objetivo essencial para promover um novo tipo de desenvolvimento. Entendese que a educação ambiental é condição necessária para modificar um quadro de crescente degradação socioambiental, mas ela ainda não é suficiente, pois se converte em "mais uma ferramenta de mediação necessária". 
Sendo assim busca-se analisar as relações sociais entre funcionários e indústria em consequência da implantação de programas de educação ambiental uso dos recursos hídricos da indústria da cervejaria, de maneira que tal responsabilidade está impregnada em todos que fazem parte desse processo, na busca da melhoria do meio em que se vivem imagens a seguir.

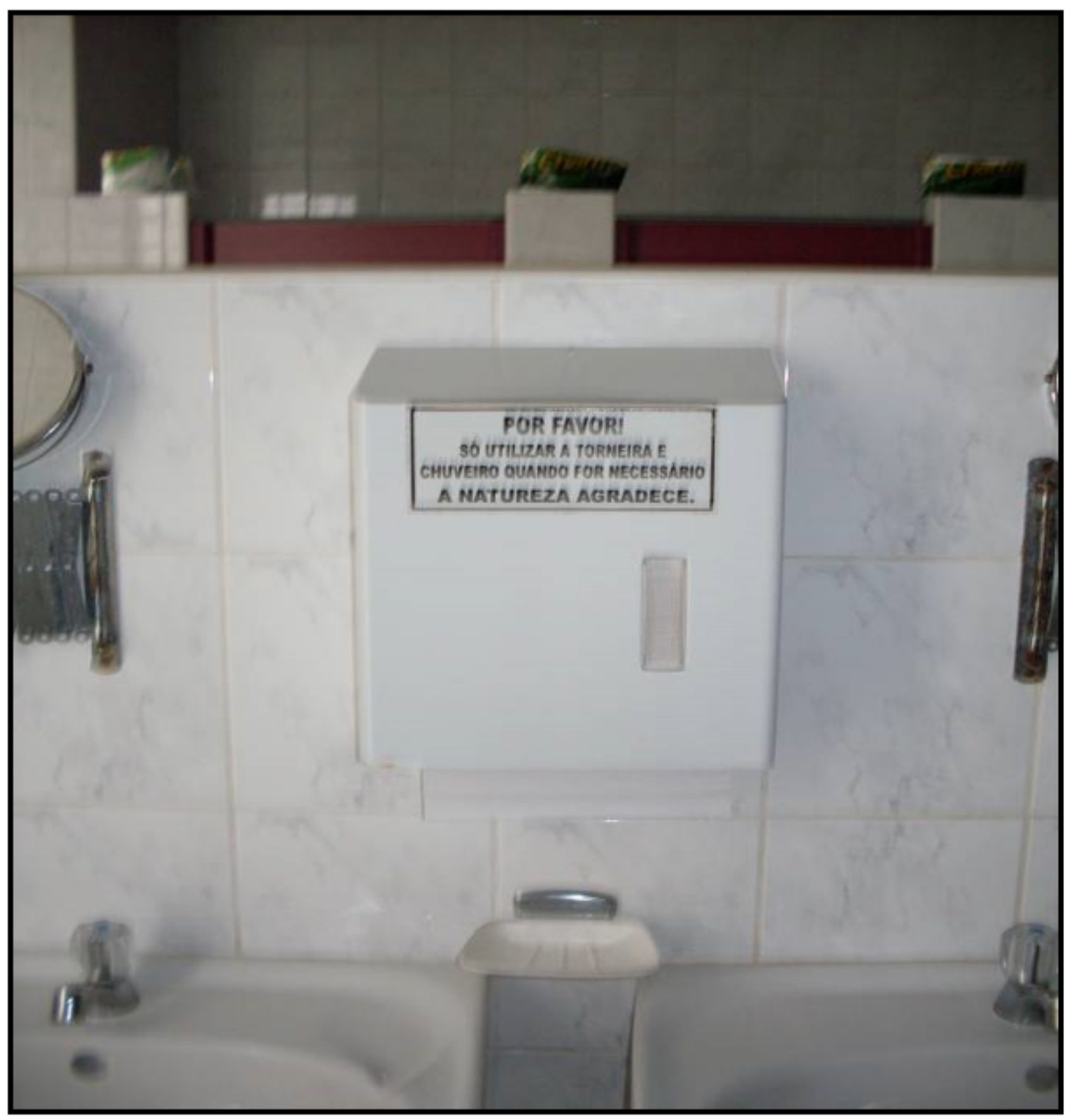

Figura 25 - Imagem interna dos vestiários e do trabalho realizado dentro da empresa e junto aos funcionários sobre educação ambiental. 
Revista Científica Multidisciplinar Núcleo do Conhecimento - RC: 1323 - ISSN: 2448-0959

https://www.nucleodoconhecimento.com.br/geografia/recursos-hidricos

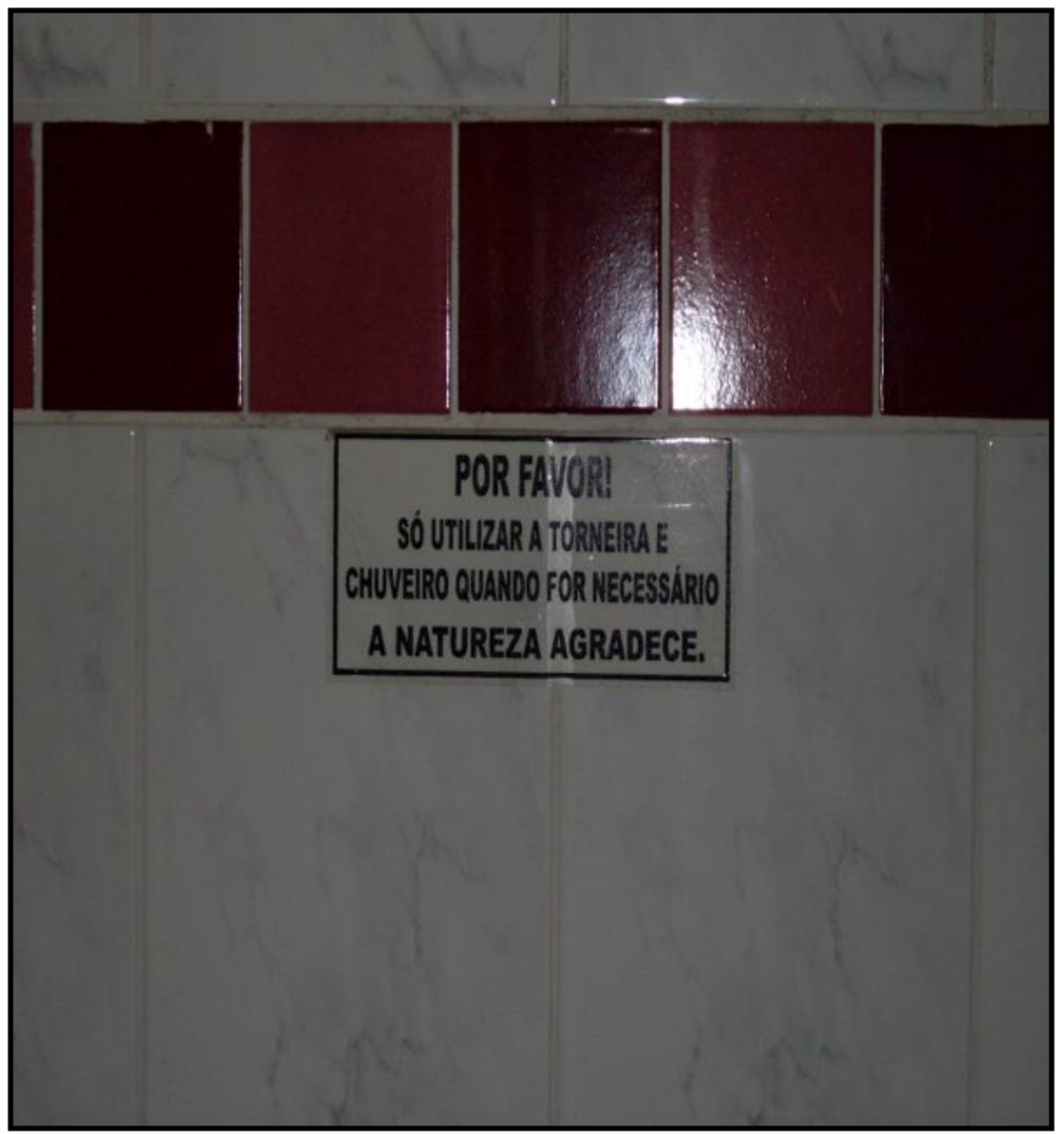

Figura 26 - Imagem interna dos vestiários e do trabalho realizado dentro da empresa e junto aos funcionários sobre educação ambiental. 
Revista Científica Multidisciplinar Núcleo do Conhecimento - RC: 1323 - ISSN: 2448-0959

https://www.nucleodoconhecimento.com.br/geografia/recursos-hidricos

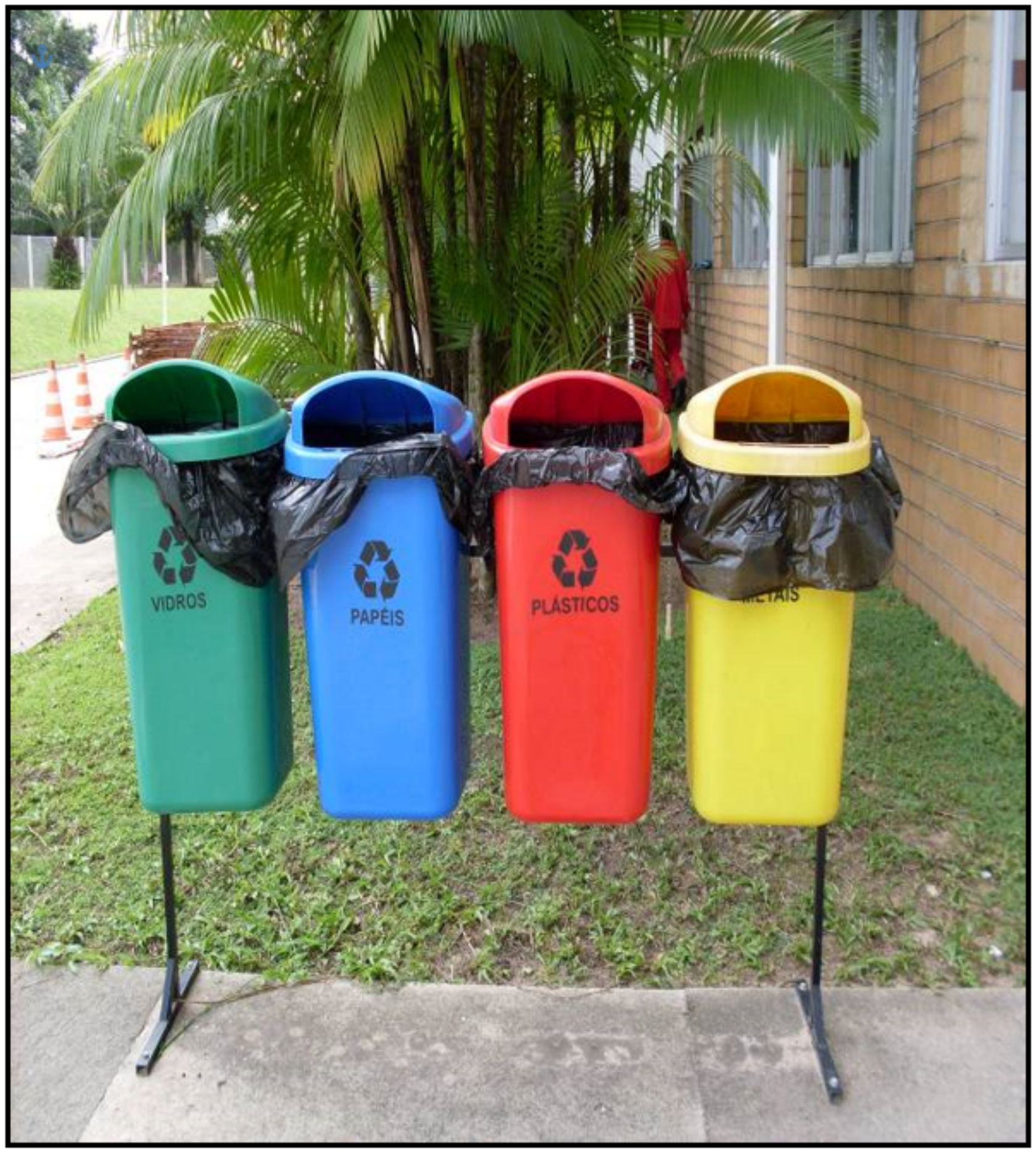

Figura 23 - Imagem externa do trabalho realizado dentro da empresa e junto aos funcionários sobre educação ambiental. 


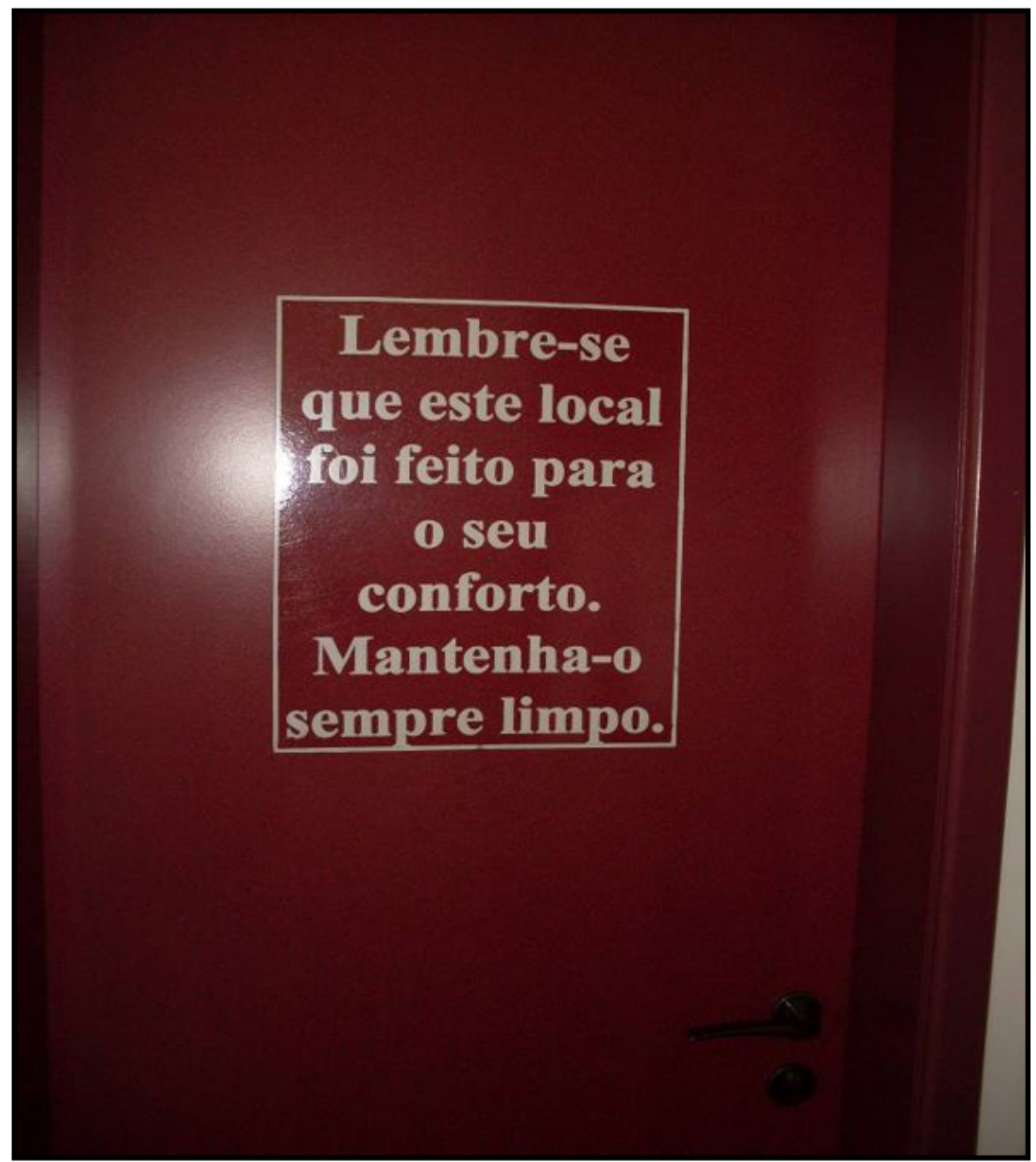

Figura 24 - Imagem interna dos vestiários e do trabalho realizado dentro da empresa e junto aos funcionários sobre educação ambiental.

A cultura organizacional é um dos aspectos fundamentais no processo de mudança, pois a cultura da empresa influencia o comportamento dos indivíduos (FERREIRA 2001). Percebeu-se que as análises ou pesquisa feita dentro da indústria de cervejaria, em especifico da cervejaria CERPASA em que, apesar de todas as dificuldades perpassadas desde sua fundação até os dias atuais, buscam-se em atitudes as mudanças necessárias impostas a toda grande indústria que se volta as questões socioambientais. Apesar 
de ser uma indústria de cervejaria, a mesma não produz somente cerveja, mas em sua cadeia produtiva há, energéticos, refrigerantes e água tônica, tudo com um rigoroso sistema de analises de qualidade exigida pelo mercado consumidor.

\section{CONSIDERAÇÕES FINAIS}

Este artigo cientifico ampliou ainda mais o conhecimento a respeito do estudo e utilização da abordagem sobre Educação Ambiental e Uso dos Recursos Hídricos dentro da indústria de cervejaria, onde todo processo de desenvolvimento da organização se fez e percorreu um longo e ardor caminho, sendo que há resistências de alguns em lidar com a questão pesquisada.

Daí porque este constitui um espaço decisório que pode viabilizar a defesa da preservação do meio ambiente e o gerenciamento dos recursos hídricos, de modo a garantir os direitos sociais do uso e acesso a esses bens, promover a equidade e a justiça social, e contribuir para o processo de democratização.

Democratização que neste contexto em que vivemos está sendo desrespeitado em sua grande maioria, por fatores que ainda envolve questões políticas e não questões realmente sérias e visando o bem estar social de todos, mas ainda pode-se viabilizar o gerenciamento entre as questões ambientais e a indústria com suas tecnologias, para isso se pega exemplos como à indústria de cervejaria neste artigo pesquisado, atitudes que fazem à diferença e que provam, onde todo o ciclo produtivo se bem trabalhado há começo meio e fim de forma o mais harmonioso possível.

Apresentou-se aqui uma breve contribuição às discussões sobre a educação ambiental e uso dos recursos hídricos, na ótica em que se conseguiu efetivamente concluir que está havendo um preparo, não somente obrigatório, mas que se busca mostrar as faces de um processo difícil de fazer ou realizar, processo no qual a indústria de cervejaria CERPASA encontra-se há anos, modificações, na sua estrutura funcional, maquinários, espaço natural ou modificado e principalmente desempenhando como ator modificador e colaborador de seus funcionários, dentro da estrutura do tema pesquisado, ou seja, de fato funciona o que neste artigo foi proposto para tal tema de pesquisa, com limitações e dificuldades governamentais, mas que, quando se quer se faz.

\section{REFERÊNCIAS BIBLIOGRÁFICAS}

ALFONSIN, B. (2001). O Estatuto da Cidade e a Construção de Cidades Sustentáveis, Justas e Democráticas. In: $2^{\circ}$ Congresso Brasileiro do Ministério Público de Meio Ambiente, Canela.

BRAGA, Elisabete et al, Joca Descobre o... Meio Ambiente. 5 ed. Ver. Recife: CPRH, 1999, 27P.

BRASIL. Política Nacional de Recursos Hídricos - Lei 9.433 de 8 de janeiro de 1997. Brasília: D.O. ou Editora, 1997. 33 p.

BRASIL, Ministério do Meio Ambiente e da Amazônia Legal: Instituto Brasileiro do Meio Ambiente e dos Recursos Renováveis. Educação Ambiental, Brasília, 1993.

FERREIRA, Ademir Antonio; REIS, Ana Carla Fonseca; PEREIRA, Maria Isabel Pereira. Gestão Empresarial: de Taylor aos nossos dias. São Paulo: Pioneira, 2001. 
MAXIMIANO, Antonio César Amaru. Introdução à administração. São Paulo: Atlas, 1995.

MAXIMIANO, Antonio César Amaru. Teoria Geral da Administração: Da Escola Cientifica à Competitividade na Economia Globalizada. São Paulo: Atlas, 2000.

ODUM, Eugenep. Fundamentos de Ecologia: Fundação Calouste Gulbenkian. Lisboa, Ed. 6a 2001.

Presidência da Câmara Técnica de Educação Ambiental - CTEA - do CONAMA Representação do MEC no CONAMA - Representação do MEC no Órgão Gestor da Política Nacional de Educação Ambiental

SITES. www.http://bndigital.bn.br - Biblioteca Nacional Digital, 2010.

SITES. www.google.com.br - Site de Pesquisa, 2010.

UNESCO.THE WORLD WATER DEVELOPMENT REPORT. Water for People, Water for Life, 2003.

[1] Geógrafo. Graduando do Curso de Pós-graduação Lato Sensu em Educação Ambiental e o Uso dos Recursos Hídricos. Faculdade Integrada Brasil Amazônia (FIBRA).

${ }^{[2]}$ Biólogo. Mestre em Biologia. Doutor em Medicina / Doenças Tropicais. Pesquisador do Programa de Pós Graduação do Núcleo de Medicina Tropical da UFPA. Professor em nível de graduação e Pós graduação e Pesquisador na Universidade Federal do Pará - UFPA.

\section{PUBLIQUE SEU ARTIGO CIENTÍFICO EM:}

https://www.nucleodoconhecimento.com.br/enviar-artigo-cientifico-para-submissao 